I NTERNATIONALMONETARY FUND

Communications Department

Frontiers of Economic Policy Communications

Prepared by Olga Stankova

No. $19 / 08$ 
Communications Department

\section{Frontiers of Economic Policy Communications}

Prepared by Olga Stankova

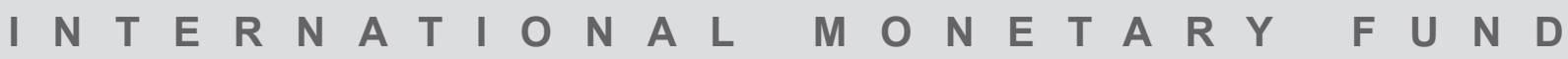


Copyright @2019 International Monetary Fund

\section{Cataloging-in-Publication Data IMF Library}

Names: Stankova, Olga. | International Monetary Fund, publisher.

Title: Frontiers of economic policy communications / Olga Stankova.

Description: [Washington, DC] : International Monetary Fund, 2019. | At head of title: Communications

Department. | Includes bibliographical references.

Identifiers: ISBN 9781498311038 (paper)

Subjects: LCSH: Communication in economic development. | Communication-Technological innovations. |

Communication in financial institutions.

Classification: LCC HD76 .S73 2019

The Departmental Paper Series presents research by IMF staff on issues of broad regional or cross-country interest. The views expressed in this paper are those of the author(s) and do not necessarily represent the views of the IMF, its Executive Board, or IMF management.

Publication orders may be placed online, by fax, or through the mail: International Monetary Fund, Publication Services P.O. Box 92780, Washington, DC 20090, U.S.A.

Tel. (202) 623-7430 Fax: (202) 623-7201

E-mail: publications@imf.org www.imfbookstore.org www.elibrary.imf.org 


\section{Contents}

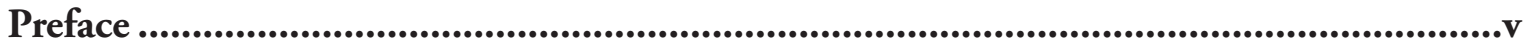

Acknowledgments................................................................................................ vi

Executive Summary ............................................................................................... vii

1. Communications -A Changing Landscape and a Growing Role .............................. 1

2. Monetary Policy Communications_Lessons and New Questions ...........................5

3. Financial Stability Communications-Still Under Development ......................... 15

4. Communications to Support Fiscal Reforms-Political Economy .......................... 23

5. Communicating in Times of Economic Crisis .................................................... 31

6. Restoring Trust-Why Does It Matter? ..................................................................... 37

7. Building Communications Capacity ...................................................................... 43

Conclusion-What Does the Future Hold for Economic Policy Communications? ..... 47

References...................................................................................................................... 49

Further Reading............................................................................................................ 55

Boxes

Box 1. The Bank of Jamaica Explains Inflation Targeting .......................................... 12

Box 2. Forward Guidance and Expectations .............................................................. 13

Box 3. Bank of England-Communications on Financial Stability ............................. 21

Box 4. Public Participation in the Budgetary Process ...................................................2 28

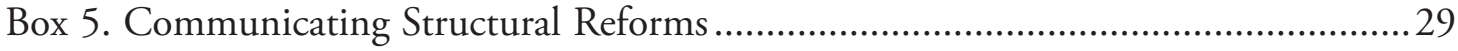

Box 6. Russia-Crisis Response and Communications ................................................35

Box 7. Principles for Public Communications in the Netherlands .............................. 41

Figures

Figure 1. Reaching New Audiences .................................................................. 10

Figure 2. Holistic Approach to Communicating Financial Stability Policies .................. 19

Figure 3. Communications and Public Participation in the Budget Process ...................24

Figure 4. Public Communications on Economic Policies Intensified During the

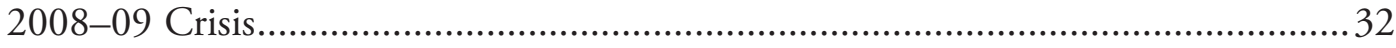

Figure 5. Mutually Supportive Messages Across Economic Policy Areas .......................3 32

Figure 6. Trust in Institutions Has Declined.......................................................... 38

Figure 7. Generalized Trust and Life Satisfaction in European Countries, 2002-14 ......39

Figure 8. Communications Tiered by Content and Channels ...................................... 44 



\section{Preface}

The environment for economic policy communications has been changing rapidly in recent years, driven by new information technologies and rising expectations for greater transparency and accountability.

The paper provides an overall view of communications across various areas of economic policy, aiming to help country authorities as they increasingly use communications as a policy tool in its own right. The paper identifies frontier communications challenges, drawing on a large body of research on the salient issues. Although communications can never be a substitute for good policies, economic reforms are more likely to fail or even be reversed if they are not understood or accepted by those whom they affect.

The role of communications is increasingly recognized in all policy areas, but the journey communications has made in central banking over the past 30 years is especially impressive: from secrecy to vagueness to transparency and accountability. The growing popularity of inflation targeting, in which communications play a central role, and increased use of forward guidance in the aftermath of the global financial crisis are important factors behind the greater attention to communications. Long gone are the days when central banks sought to "keep the press out of the bank and the bank out of the press," and there is no going back.

However, there is room for one policy area to draw from experiences in the others. The paper discusses current and prospective developments in communications on monetary, financial stability, fiscal, and structural policies. It also considers the role that communications can play in helping to strengthen public trust in institutions. The country examples have been chosen to highlight issues that arise and recur in a wide range of political systems and economic policy frameworks.

The paper's objective is to provide readers with a useful guide to emerging issues in economic policy communications and stimulate further reflection.

Gerry Rice

Director, Communications Department 


\section{Acknowledgments}

I wish to thank my many colleagues at the IMF who provided comments on and support for this paper. Above all, I owe a debt of gratitude to Gerry Rice and Christoph Rosenberg, who strongly supported the proposal for a paper to tackle this subject and made several rounds of insightful comments. Others who provided comments and suggestions (in alphabetical order) include Tobias Adrian, Camilla Andersen, Ari Aisen, Shekhar Aiyar, Nazim Belhocine, Sabina Bhatia, Luis Brandao Marques, Daniel Garcia-Macia, Vitor Gaspar, Gaston Gelos, Gita Gopinath, Jeff Hayden, David Hoffman, William Kerry, Amit Khetarpaul, Kate Langdon, Martin Muhleisen, Erlend Nier, Maurice Obstfeld, Olivier Puech, Ricardo Cicchelli Velloso, and Rhoda Weeks-Brown. I would also like to thank Houda Berrada, Joe Procopio, and Linda Long for editorial support; Chrystal Herrmann for the graphics; and Julie Papikova and Teresa Zosa Evaristo for administrative assistance. 


\section{Executive Summary}

The environment for economic policy communications has been changing rapidly in recent years, posing new challenges and opening new frontiers. The growth of the internet and social media has made it possible for ever more people to express their views on public policies and has contributed to rising expectations for transparency and accountability, even as trust in institutions and experts has declined. Economic policy institutions are likely to continue to face pressures to explain their policies to a broader public and show that they merit support.

Policymakers will likely need to work harder in the future to make their messages heard and believed. As the level of noise in the information space continues to rise, transparency and disclosure, although essential, may no longer be enough. Proactive communications, harnessing new technologies, and using multiple channels, with many different paths from the sender to the receiver, are coming into widespread use. Messages will need to be trustworthy and convincing, and better tailored to different audiences. More than ever, communications will be an important policy tool.

Communications on monetary policy have become more challenging in many countries, owing to slower economic growth, low real interest rates, the effects of monetary policy on financial stability, and in some cases challenges to central bank independence. Central banks, for their part, have begun to reach out more systematically to a broader public to explain and justify their policies while continuing to strengthen communications with financial markets.

Financial stability communications increasingly aim to cover the full policymaking process. A more holistic approach, based on clear strategies and protocols, along with improved coordination, both at the national and international levels, will continue to develop. This can help make financial stability communications more systematic and strategic, and more relatable to a broader public. 
Communications on fiscal and structural policies need to persuade as well as inform. Increased public participation in the budget processcommunications in both directions - can support greater realism about fiscal policy and raise awareness of the need for sustainable public finances. Convincing the public of the benefits of deeper fiscal and structural reforms, in areas such as energy subsidies or labor markets, can require extended information campaigns.

Crisis responses entail changes in many policies. Across monetary, fiscal, financial, and structural policies, strong coordination of communications is essential so that all facets of policy support each other during a crisis. A coordinated approach can help to raise confidence and reduce the ultimate costs of the crisis. Crisis preparedness exercises would regularly include a communications component.

Restoring trust in institutions is necessary to improve economic well-being. This is a difficult task that requires not just sound policies but also truthful and trustworthy conduct by policymakers and other members of society, accompanied by more meaningful transparency and public participation, and more effective communications and impact assessments. 


\section{ChAPTER}

\section{Communications-A Changing}

Plus ça change, plus c'est la même chose (The more things change, the more they stay the same) Jean-Baptiste Alphonse Karr (1808-90), French writer and editor of Le Figaro

The objectives of communications - notably mutual understanding and support - are much the same today as they have been historically. Policymaking involves the communication of ideas and information. This has been true over time and in a wide range of political systems, despite obvious differences in views on the role of public debate and the flow of information.

Although communications have always been a powerful tool, ${ }^{1}$ the understanding of the why and how of communications has deepened in recent decades. The systematic use and study of media and mass communications intensified in the 20th century, and these insights are being applied in economic policy communications. For example, the impact of central bank communications on financial market reactions and economic agents' expectations has been closely studied, helping to inform monetary policy and how it is communicated.

There has been also growing use of large-scale communications campaigns in support of fiscal and structural reforms. Some reforms (for example, eliminating fuel subsidies) may be painful and unpopular but still necessary for sound public finances, the efficient use of energy, and to ensure that resources reach those most in need of them. Other reforms, such as certain kinds of deregulation, may be popular but face opposition from vested interests. Communications help by explaining the benefits of reforms and the motivations of

\footnotetext{
${ }^{1}$ For example, see "Government Communication as a Policy Tool: A Framework for Analysis" (Howlett 2009).
} 
the vested interests opposing change. Without buy-in and support from the broader public, there is a higher risk that reforms will fail or even be reversed.

Technological change is also fundamentally altering the communications landscape, posing new challenges and opening new frontiers. Much of the world is already hyperconnected, and in the next 10 years almost everyone in the world will have access to broadband. When everyone has a voice, influence becomes more dispersed and the public's relations with institutions are transforming. Activism on social media has at times given rise to public campaigns - for example, the movement to "audit the Fed." ${ }^{2}$ There are also risks from new forms of deception and disinformation, which are spreading rapidly. ${ }^{3}$

Many economic policy institutions increasingly communicate with a broader audience, and not just with experts, emphasizing their accountability to society as a whole. Indeed, this is a key unifying theme across different areas of economic policy. Disseminating information more widely and quickly to engage and convince the public is becoming increasingly important for policy institutions (including those with operational independence), and in a wide range of political systems. Policymakers face the task of explaining to increasingly vocal and diverse audiences that their policies deserve support, while also counteracting false claims and beliefs. This has become more challenging, with polls consistently showing that, in many parts of the world, dissatisfaction with public policies has risen and trust in institutions and experts has declined.

A central challenge for economic policymakers in this environment is having their messages heard, understood, and believed. Declining trust, rising noise, growing competition for attention, and the inherent difficulty of explaining complex economic concepts to a broader public mean that transparency and disclosure remain important but are no longer sufficient. ${ }^{4}$ To be effective, communications need to be proactive and use multiple channels, multiple times, with many different paths from the sender to the receiver. ${ }^{5}$

It will be increasingly important to continuously upgrade the communications toolkit. This may include using insights into behavior from psychology,

\footnotetext{
2The Federal Reserve has prominently placed a link on its website asking, "Does the Fed ever get audited?"

${ }^{3}$ One example is "deep fakes," which is false audio or video created using artificial intelligence (Chesney and Citron 2019).

${ }^{4}$ Stephen Poloz, Governor of the Bank of Canada, has noted that: "transparency is only helpful if people can understand what we are saying" (Poloz 2018).

${ }^{5}$ For example, the IMF has a transparency policy and a communications strategy. The transparency policy determines which documents will be disclosed and when, and the degree of transparency. The communications strategy seeks to ensure, among other things, that IMF policies and advice are understood by the public.
} 
cognitive science, and social science ${ }^{6}$ along with the ethical use of techniques such as tiered communications and audience segmentation. Messages that connect with the intended audiences' needs and interests (that is, relatability) can also help to build understanding. ${ }^{7}$ Most importantly, communications need to be credible and believable. That said, communications can never be a substitute for good policies and trustworthy conduct by policymakers.

There are significant differences in communications across economic policy areas. In monetary policy, communications often take place within a well-established policy framework, and there is a large empirical literature on how communications work. ${ }^{8}$ In financial stability policy, the framework is still developing, and less is known about the most effective way to communicate. In fiscal and structural policies, political economy is often at the very forefront of communications, with a high premium on both listening to and persuading the public. And, in a crisis, action may be required simultaneously in many policy areas, and coordinating communications is the primary challenge. More generally, there is room for one area of policy to draw from experiences in the others.

An overarching issue connecting all areas of economic policy communications is low trust (Edelman 2019). The paper discusses the extent and possible causes of the problem and considers a range of possible measures-all of which require skillful communications - to address it. Some countries may benefit from capacity building in communications, with improved practices that are also mindful of the need to maintain and build trust.

${ }^{6}$ The Organisation for Economic Co-operation and Development (OECD) recently released the first global collection of over 100 case studies on using insights from the behavioral sciences to improve public policy (OECD 2017b).

${ }^{7}$ The Bank of England has been among the pioneers in this field. A key finding in Bholat and others (2018) is that enhanced relatability improved public understanding compared to the traditional monetary policy summary.

${ }^{8} \mathrm{~A}$ selection of this literature is discussed in the following section, on monetary policy communications. 



\section{Chapter}

\section{Monetary Policy Communications- Lessons and New Questions}

... sometimes, the explanation is the policy. Janet Yellen, speech to the Society of American Business Editors and Writers,

April 4, 2013

In the past decade, the environment for monetary policy has become more challenging in many countries, reflecting slower economic growth, lower real interest rates, a renewed attention to the interdependence of monetary and financial stability, and concerns about the distributional effects of low interest rates (Bernanke 2012). Also, the operational independence of central banks in monetary policy has been challenged in some cases (Obstfeld 2018).

Central banks have adapted in part by stepping up communications. Although central banks have on the whole been clearly heard by financial markets and economists, the broader public has hardly been reached (Haldane and McMahon 2018). A growing number of central banks, operating under a wide range of different monetary policy regimes, are now investing in new communications practices and technologies, including social media and direct outreach to a broader audience. Explaining policies to the public, and thus emphasizing accountability to society as a whole, is important.

Communications can help explain the central bank's objectives, policy framework, and policy decisions to a broader audience. Even so, for communications to be effective, policies need to be sound, with clear objectives and a well-defined framework, and with policy decisions that are consistent with the objectives and framework. Otherwise, communications could even amplify weaknesses and inconsistencies. 


\section{Communications on the Policy Framework}

Communications play a crucial role in establishing and supporting the credibility of the monetary policy framework and the independence of the central bank. In almost all countries, the government is responsible for setting the overall monetary policy framework, often through legislation. Government communications that support - rather than undermine - the monetary policy regime can enhance the effectiveness of policy, all the more so when coupled with government support for central bank independence and accountability. ${ }^{1}$

Canada provides an example of how this can work. Every five years, the government and the Bank of Canada formally renew the Inflation Control Target. Both the government and the central bank see the renewal process as a strategic communications opportunity. The process typically begins with a joint statement by the government and the Bank of Canada, ${ }^{2}$ and many different kinds of communications and outreach are used to foster public engagement and debate, with a focus on the benefits of low and stable inflation.

\section{Communications under Different Policy Regimes ${ }^{3}$}

Monetary policy communications need to deal with three broad cases: when the monetary policy framework is already well defined; during transitions from one framework to another; and when the framework is more discretionary or frequently changing. Most of the research to date has focused on various forms of inflation targeting, in which communications are integral to the policy process. Less attention has been given to communications under other types of monetary regimes.

Contemporary inflation targeting is mostly inflation forecast targeting, and central bank communications are an essential tool for influencing and anchoring inflation expectations. Many central banks publish macroeconomic forecasts and provide forward guidance on policy. These kinds of communications are generally transparent and systematic, aiming to explain what the authorities have done, and why, to achieve their inflation-targeting objectives.

Communications in monetary regimes that rely on exchange rate anchors face a different set of challenges. The credibility and sustainability of a pegged

\footnotetext{
${ }^{1}$ For an international comparison of inflation targeting framework reviews and revisions, see Wadsworth 2017.

${ }^{2}$ Joint Statement of the Government of Canada and the Bank of Canada on the Renewal of the Inflation-Control Target (October 2016).

${ }^{3}$ Most large advanced and emerging economies have adopted some form of de facto inflation targeting, while other types of monetary regimes are more commonly found in emerging markets and developing economies.
} 
exchange rate depends on the consistency of the peg with macroeconomic policies more broadly, and also on whether foreign exchange reserves are sufficient to weather a large range of external shocks. Communications in these regimes would thus focus on conveying the soundness and consistency of the policy framework to various audiences, especially participants in the foreign exchange market.

Yet another set of challenges arises in emerging and developing economies that are transitioning from one monetary policy regime to another (IMF 2015c). These transitional regimes include cases in which a country is moving away from an exchange rate anchor or traditional monetary targeting and toward some form of inflation targeting. Clear communications about the goal and sequencing of the transition can play a crucial role in building credibility and enhancing the effectiveness of monetary policy. Box 1 discusses the case of Jamaica, which is moving toward full-fledged inflation targeting over the medium term.

Finally, some monetary policy regimes are essentially discretionary. At times they may rely on a hard or soft exchange rate peg, at times on monetary targeting, or at times on a combination of anchors, and sometimes they have no well-defined or durable nominal anchor. Monetary policy communications under these conditions will be difficult and may be prone to inconsistency. IMF policy advice in such cases has emphasized transitioning to a better-defined and more stable policy regime, which would also allow communications to play a more effective role.

\section{Less May Be More, and Limits to Communications}

More is not always better in central bank communications, and there is not yet a full understanding of "how much is enough." The quality of communications, and in particular their consistency, both internally and over time, may be more important than the quantity. It has been said that a central bank that speaks with too many voices may have no voice at all (Blinder 2004). Some recent research supports this view: too many slightly different speeches by monetary policymakers could be a source of noise rather than clarity (Lustenberger and Rossi 2017). Publishing the minutes or transcripts of internal policy deliberations can also be a two-edged sword. Although these documents provide information on the thinking and plans of policymakers, they may also be difficult to interpret, especially when conditions are changing rapidly. Relatedly, some central banks impose a blackout period on communications in the days before a policy decision to help messages related to the announcement stand out and be clearly heard. 
Communications are a powerful policy tool, but also have limits. When inflation expectations are strongly anchored, central banks can accomplish more through communications, with less need for actions. However, there are risks in placing too much reliance on communications when action is what is needed. In such cases, expectations can become unanchored and credibility can erode, also undermining the effectiveness of communications in the future.

\section{Evolving Views on Communications Under Inflation Targeting}

Forward guidance under inflation targeting continues to develop (Box 2). Although some inflation-targeting central banks publish a quantitative path for their policy rate, others consider that there are downsides to this practice. One important issue is how much certainty the central bank should convey to the public about its outlook for the economy and for monetary policy. When the central bank gives an overly strong impression of certainty, financial markets may no longer react adequately to incoming data. Conversely, conveying high uncertainty may undermine confidence. Finding the right balance can be challenging, all the more so as it is often desirable to avoid large discontinuities in messaging that could affect expectations in unwanted ways.

A related issue is how to communicate about the central bank's forecast. There are many options and choosing the best one is not always straightforward. For example, the central bank could communicate that the forecast reflects the view of its policymakers. Alternatively, it could present the forecast as a staff product that provides one input among others to the policy deliberations (Al-Mashat and others 2018). How to communicate the forecast will depend, among other things, on the structure of the decision-making process in the central bank (Lambert 2006). For example, when there is a monetary policy committee, it may not be credible to assert that all committee members share the same view on the economic outlook. Careful thought also needs to be given to the way in which risks to the forecast are communicated (for example, the width of the fan charts and how the risks are described), and how risks influence policy decisions.

In coming years, central banks with inflation targets may need to communicate adjustments to their policy frameworks if low levels of neutral real interest rates are sustained, which may increase the likelihood that the policy interest rate will hit the effective lower bound. ${ }^{4}$ Options include targeting average inflation over longer horizons, price level path targeting, and new

${ }^{4}$ Based on experience so far, the effective lower bound on nominal interest rates is either zero or slightly negative. 
types of unconventional monetary operations (Williams 2018). Clear and proactive communications will be essential to ensuring that any changes to the policy framework do not undermine price stability and central bank operational independence.

\section{Communicating on Financial Stability}

Central banks often have an important role in financial stability, in addition to monetary policy. The development of macroprudential policy frameworks has reinforced this role, with many central banks now having at least some responsibility for macroprudential policy. Current best practice emphasizes the importance of separating communications on the two areas of policy, reflecting the separation of objectives, decision-making structures, and accountability mechanisms (IMF 2013, 2014).

Even so, there are many interactions between monetary policy and financial stability. The conduct of each policy can have side effects on the other (Nier and Kang 2016), which also have implications for communications. For example, there is a long-standing debate on whether central banks should use monetary policy tools, notably interest rates, to "lean against the wind" to help maintain financial stability. ${ }^{5}$ The IMF currently takes the view that pursuing a financial stability objective in the conduct of monetary policy-in addition to the price and output stability objectives - can create substantial challenges in communications and reduce the credibility of the central bank's inflation targeting framework (IMF 2015d).

Central banks are developing communications strategies for monetary and financial stability policies separately, and for their interactions. It would be beneficial for such strategies to be guided by the principles discussed above. Some of these issues are discussed further in the section on financial stability communications.

\section{Reaching New Audiences in a Changing Information Environment}

Central banks are increasingly communicating beyond "markets, economists, and newswires" (Haldane 2017a). Many central banks are doing more to explain their policies to a broad public to enhance understanding and support. This is not an easy task. Challenges include greater noise on social media and the fragmentation of audiences in internet echo chambers. In

\footnotetext{
5Under a policy of "leaning against the wind," the central bank for some time sets a policy interest rate that is slightly higher than needed purely to maintain price stability to counteract the buildup of financial vulnerabilities.
} 
Figure 1. Reaching New Audiences

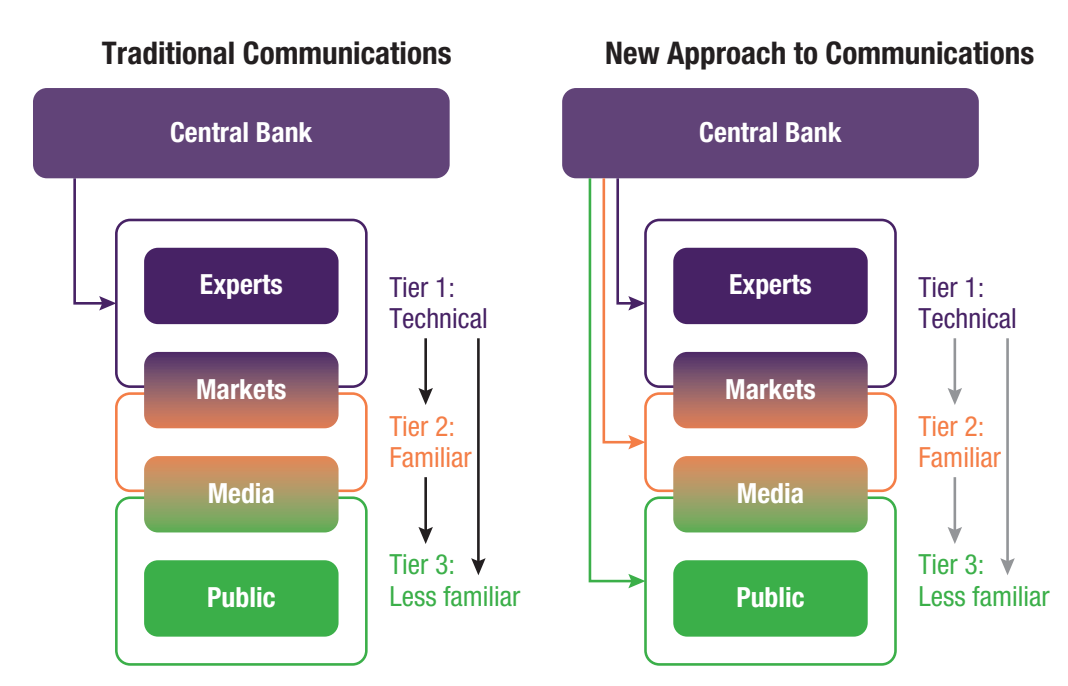

Source: IMF staff.

some countries, media capacity to report on the complexities of monetary policy is still being developed while, in others, the market for economic and financial news is too small to sustain high quality reporting.

A growing number of central banks are trying to reach their audience directly (Figure 1). ${ }^{6}$ Tools for intermediary-free access to various audiences include not only the website and a broader social media presence, but also educational programs in schools and central banks' museums, more direct outreach to civil society organizations, and workplaces. Communications are being increasingly tiered, with products at different levels of technicality depending on the targeted audience. Messages are also being regionalized; for example, the Federal Reserve Bank of Dallas uses Twitter to highlight regional economic research (@DallasFedComDev).

Some central banks have launched new publications aimed at a general audience. The Bank of England recently started a "Bank Underground" blog. It is written at a ninth grade reading level but, even then, it can only be understood by about 30 percent of the country's population. There is clearly still some way to go in making monetary policy messages accessible and relatable to a broader public.

In order to communicate better, it is also important to listen. Central banks are making growing use of opinion surveys. For example, the Bank of Can-

\footnotetext{
${ }^{6}$ Examples include the Bank of England's regional outreach, including to schools, and interviews by Federal Reserve chairs Bernanke and Powell on general interest television news programs.
} 
ada's "Public Awareness and Communications Survey 2018" found that knowledge of the central bank is limited, but that despite some negative perceptions, trust is generally high, mainly because the central bank is viewed as doing a good job controlling inflation. Various forms of "listening" allow central banks to get feedback on how their work and communications are received by the public, and to experiment with new approaches.

New information technology also means that false information can spread more rapidly and widely. Central banks have in some cases developed a quick response capacity to put out "wildfires" on social media. One example is Nigeria, where numerous social media accounts were impersonating the governor and spreading false messages, and rapid action was needed to close them (Central Bank of Nigeria 2013). Relying on external fact-checkers and traditional media has proven insufficient (some so-called fact checks can turn out to be "fake news"). Central banks are thus increasingly focused on transmitting their messages directly to the intended recipients.

Reaching a wider audience, including nonresident investors in domestic financial markets, also means communicating in more languages. The People's Bank of China recently revamped its English language website and aims to simultaneously release information in both Chinese and English. The ECB faces the challenge of communicating in 23 languages of the euro area countries. The Reserve Bank of South Africa operates in a country that has 11 official languages. 


\section{Box 1. The Bank of Jamaica Explains Inflation Targeting}

Jamaica aims to transition to full-fledged inflation targeting over the medium term, with amendments to the central bank law introduced in Parliament in late 2018. One of the key challenges for the Bank of Jamaica (BOJ) has been to explain the benefits of the new monetary policy regime to a public long accustomed to focusing on the exchange rate. To this end, the BOJ has taken decisive steps to strengthen its communications capacity, and is implementing innovative public relation campaigns to take its message on the benefits of price stability directly to the broad public.

The BOJ has published a communications strategy to further bolster the transparency and credibility of the policy transition. In addition to an increased presence on social media and easily understood headline messages in routine monetary policy communications, $\mathrm{BOJ}$ is deploying radio advertising and billboards with powerful messages inspired by Jamaica's popular culture, including Reggae music. This initial intensive campaign would be followed up by sustained messaging over a period of several years, accompanied by surveys to measure its effectiveness and be adjusted and refined. A review of the BOJ's experience in a few years' time may hold important lessons for other central banks. 


\section{Box 2. Forward Guidance and Expectations}

Forward guidance is communication by the central bank about the future course of monetary policy. Forward guidance can have strong effects on expectations, not just in financial markets, but in the economy as a whole, helping expectations to become a stabilizing force.

The form and content of forward guidance has varied across central banks and over time. One form signals a commitment to act a certain way in the future, at a specific time or if a specified event occurs (Odyssean forward guidance). More commonly, central banks prefer to reserve some flexibility, and instead provide information about what the central bank might do (Delphic forward guidance). As with other central bank communications, it appears that forward guidance may have had relatively little impact on the perceptions of the broader public, beyond financial markets (Haldane and McMahon 2018).

Guidance about future policy is provided by almost all central banks with a formal or informal inflation targeting framework. Some central banks, such as Sweden's Riksbank, publish the expected future path of policy interest rates consistent with their overall economic outlook. The U.S. Federal Reserve provides the distribution of the views of members of its policy committee on future short-term interest rates (the "dot plot"), but without identifying the members by name. The ECB provides mainly qualitative guidance on the future path of policy.

Forward guidance was also used by central banks facing the effective lower bound on policy rates to communicate a more accommodative policy stance. One important form of such guidance was that policy interest rates would remain "lower for longer" than conventional monetary policy reaction functions would imply (Yellen 2013).

The effect of forward guidance on expectations in financial markets can be swift and powerful. For example, the ECB has lately used forward guidance to help reduce growing market uncertainty about the timing of its interest rate liftoff. The guidance provided by the ECB in June 2018 immediately reduced measures of market uncertainty about the future course of money market rates (Coeuré 2018).

While forward guidance is a powerful form of central bank communications, there are risks in overusing it. By providing too much (and probably illusory) certainty to markets, a central bank can foster complacency and herding among market participants, and may also reduce the information content of the market prices that help to inform its own policy decisions (Morris and Shin 2018). This recognition has led the Bank of Canada, for example, to scale back its forward guidance since 2014, to incentivize financial markets to place more weight on incoming data and not rely overly on the central bank for information on where the economy is headed (Poloz 2018). 



\title{
ChAPTER
}

\section{Financial Stability Communications- Still Under Development}

\author{
In finance, everything that is agreeable is unsound \\ and everything that is sound is disagreeable. \\ Winston Churchill, Churchill by Himself: The Definitive Collection of
}

Quotations, 2008

The financial crises of the last decade have undermined public trust and may have contributed to the rise of populist political movements in some countries. ${ }^{1}$ The global financial system is now safer than in the mid-2000s owing to substantial improvements in regulation, supervision, and risk surveillance, with greater attention to systemic risk and the development of macroprudential frameworks (IMF 2018d). Even so, polls indicate that public confidence in the financial system remains low in many countries (Edelman 2019).

Further strengthening communications on financial stability remains a high priority. Effective communications can help to make the financial system more resilient. Provided that policies are fundamentally sound, communications can allow market participants and the public to make more realistic risk assessments, which in turn can bring about behavioral changes and strengthen market discipline. Some of the areas still in progress are discussed in what follows.

\section{Communicating the Objective of Financial Stability Policy}

Effective communications on financial stability require clearly articulating the policy objective. Only in recent years has a broad international consensus

\footnotetext{
${ }^{1}$ As IMF Managing Director Christine Lagarde recently said, "And we know that there is a widely-shared perception that those who caused the crisis did not face the consequences, while ordinary people paid a heavy price. Many people actually saw this as the ultimate breach of public trust" (Lagarde 2019).
} 
begun to emerge on the definition of financial stability as the ability of the financial system to withstand a variety of shocks so that economic performance is not adversely affected. The IMF, in its Global Financial Stability Report (GFSR), has offered a concrete and measurable definition: Growth at Risk, or downside risks to output as a result of vulnerabilities in the financial system (IMF 2018b). The definitions are becoming clear, sharp, and simple enough to allow the public to understand what policy is trying to achieve.

\section{Ensuring the Coherence of Policy Messages}

The financial system has many parts, as do financial stability policies: a key communications challenge is to ensure that policy messages are clear and coherent. Clearer and more coherent messaging may in some cases require further progress in articulating the policy framework (for example, the relationship between microprudential and macroprudential policies), or the interactions of financial stability policies with other policies. Vested interests in the private sector, bureaucratic rivalries, and international relations issues may at times raise obstacles to clear communications on financial stability policies.

The complexity of the financial system also makes policy communications challenging. A wide range of different economic agents are involved in finance, from large institutional investors to individual depositors. There has been strong growth in recent years in the share of non-bank financial activities (for example, systemic insurance companies, computerized trading, investment funds, and central counterparties), which in turn interact with the banking sector. There is also contagion and cross border propagation of systemic risks. These issues are often very complicated and difficult to explain, even to experts. Persuasively conveying the main messages to a broader public will be a challenging yet crucial task in the years ahead.

Policies to safeguard financial stability have correspondingly many facets, including microprudential regulation and supervision, macroprudential policies for banks and nonbanks, financial stability indicators, stress testing, asset quality reviews, and bank restructuring and resolution. Responsibility for financial stability policies is often spread over several agencies, and also involves international commitments, with implications for the coherence of communications.

To improve coordination and communications, many countries have established financial stability committees, with all key agencies participating: central bank, financial services authority, ministry of finance, and a deposit 
insurance fund. ${ }^{2}$ In Indonesia, for example, the Financial System Stability Committee, which meets four times a year, releases a statement and holds a press conference after each meeting to inform the press and public of their assessment of financial stability in the country.

\section{Communicating the Broad Policy Framework and Systemic Risks}

A national financial stability or macroprudential strategy ${ }^{3}$ can help authorities explain to the public the main elements of the financial stability policy framework and how they interact and develop over time. Slovenia, for example, first published a macroprudential strategy in 2015, which was updated in 2017, reflecting the rapid pace of developments in the field. By clearly communicating the changes to the framework, authorities can signal that the ongoing development of the financial stability policy is receiving the necessary attention.

Financial stability reports (FSRs) have become one of the main vehicles for communications on systemic risk and related policies. ${ }^{4}$ The objective of these reports is usually to provide a systemic perspective on financial stability, which can help to support stronger market discipline and provide a rationale for policy action when needed. The GFSR, for example, flagged some key risks in the early stages of the global financial crisis (Gennaioli and Shleifer 2018). 5 The publication of FSRs has had a measurable effect on market conduct (Born and others 2011). In communicating with a broader public, a key challenge is to pervasively convey the need for policy action to prevent financial instability and limit GDP (or welfare and jobs) at risk.

Growing efforts are being made to convey key messages from FSRs to a broader audience. For example, the Reserve Bank of New Zealand has started to include a graphical presentation of key developments and policy actions in its FSR, along with headline messages in plain language. Agencies respon-

\footnotetext{
${ }^{2}$ Edge and Liang (2019) argue that a key motivation for setting up financial stability committees is to improve coordination and communication among agencies. This could also support improved public communications.

${ }^{3}$ The European Systemic Risk Board (ESRB) and the European Central Bank have published a series of documents on macroprudential policies, ranging from broad strategy to detailed technical work. Notably, in 2015, the ESRB published a handbook on operationalizing macroprudential policies, which includes guidance on communicating these policies. The ESRB also publishes its regular annual review of macroprudential policy in the EU. These publications have been helpful in communicating macroprudential policy to specialists and the broader public.

${ }^{4}$ As of late 2018, more than 60 countries were publishing financial stability reports. The IMF has published its Global Financial Stability Report since 2002.

${ }^{5}$ FSRs serve to identify vulnerabilities in the financial system. They may be complemented by early warning exercises, on which there is a large literature; see the references in Aldasoro, Borio, and Drehmann 2018, and Shin 2013.
} 
sible for financial stability policies are also increasingly using social media to disseminate visual messages summarizing the main findings of their FSRs.

It is important for communications strategies to spell out the linkages between financial stability policies and other policy areas, notably monetary policy. Some argue that while central banks have adopted the necessary institutional arrangements to communicate a price stability objective, their communications strategies are less suited to dealing with financial stability issues, also given that other agencies are typically involved in financial stability policies too (Siklos 2014).

\section{Communicating Specific Policy Actions}

While broader documents such as financial stability strategies and FSRs can help the public to see the big picture, it can also be important to explain individual policy actions. This is especially true of macroprudential measures. For example, it has proven difficult to persuade the public that measures to limit bank exposures to the housing market did not aim to control housing prices (Donnery 2017). Such misunderstandings can lead the public to question the effectiveness and credibility of the measures. While uncertainty about the effects of macroprudential instruments will gradually be reduced through improved quantification and calibration, progress will also be needed in explaining measures in a convincing way that relates to audiences' interests.

The IMF has established guidance for communicating macroprudential policies. These include the publication of a macroprudential strategy, periodic reports covering issues such as risk assessments, macroprudential policy implementation, and ex-post assessments of policy effectiveness. In addition, publication of a record of the meetings of macroprudential decision makers can also be beneficial (IMF 2014). The experience of the Bank of England is discussed in Box 3.

What holds for macroprudential policies also applies to microprudential measures and regulatory changes. Changes in microprudential policies can have a significant impact on the conduct and risk profile of financial institutions. Communicating any significant changes throughout the policy cycle is therefore important to avoid surprises and excess volatility. Authorities are also increasingly holding public consultations to explain how new regulatory proposals support financial stability. The complexity of the issues involved requires care to avoid misunderstandings in the press and public.

Communicating the results of bank stress tests and asset quality reviews in a way that supports financial stability remains a challenge. Communications 
Figure 2. Holistic Approach to Communicating Financial Stability Policies

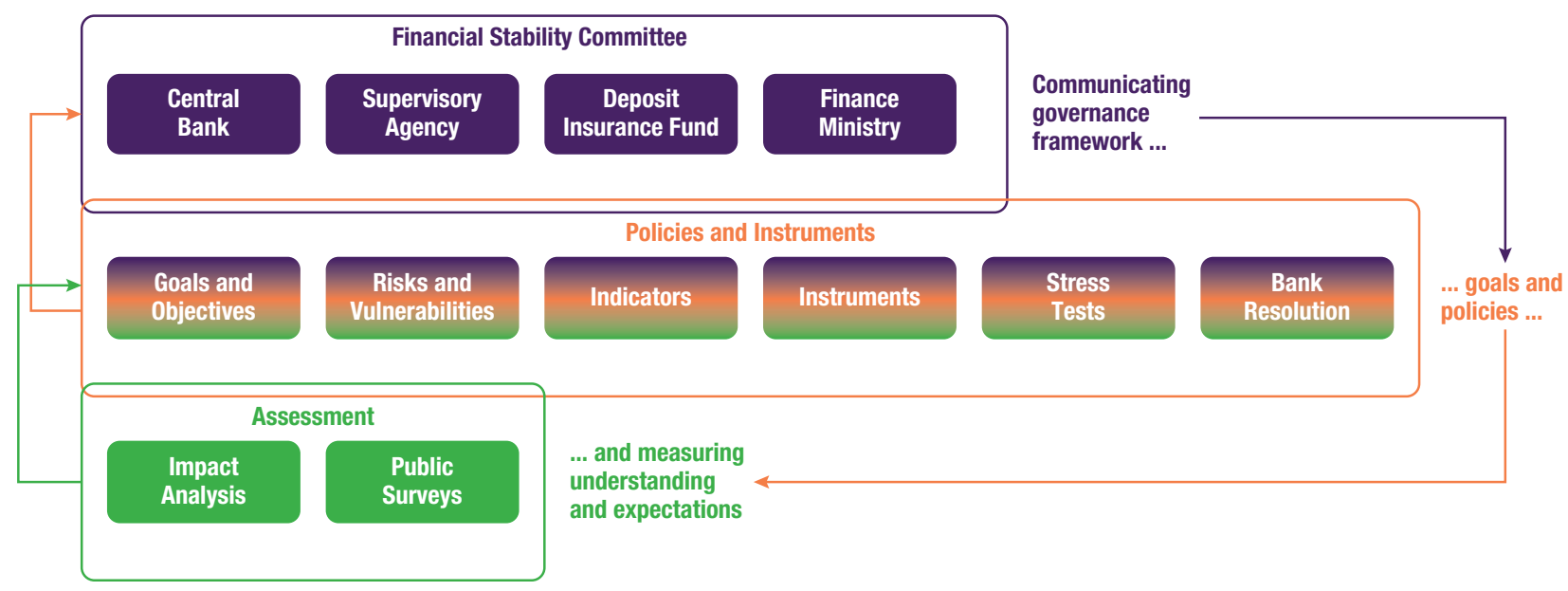

Source: IMF staff.

in this area need to find the right degree of transparency about systemic risks, exercise caution in the release of information on individual institutions to avoid self-fulfilling expectations and destabilizing bank runs, explain the policy changes needed to correct the problems uncovered, including the communication of any bank closures, and clarify that the scenarios used for stress tests are hypothetical and not forecasts. When the U.S. authorities, for example, published the results of the comprehensive bank stress tests in 2009, they exposed the extent of banking system problems but also restored confidence by communicating corrective actions and showing a path forward.

\section{Towards a Holistic Approach}

Financial stability frameworks have rapidly developed in recent years and are being more clearly articulated. Policymakers are now in a much better position to explain them. This also provides an opportunity to make financial stability communications more systematic and strategic, aiming to explainas in monetary policy communications - what the authorities have done, and why, to achieve their policy objectives (Figure 2). Doing so will enable communications to take their place as a core tool of financial stability policies (as also noted in Bank for International Settlements 2018 with reference to macroprudential policies).

Countries will benefit from developing a holistic approach to financial stability communications, with strategies and protocols aiming to cover the complete financial stability policymaking cycle: from the identification of the problem, to the debate on possible policy actions and their eventual announcement, to follow up on their effectiveness. 


\section{Communications on International Financial Stability Policy}

The global nature of finance also requires communications on international financial stability. ${ }^{6}$ International bodies such as the Financial Stability Board (FSB) and IMF, or the EU, have established strong transparency and disclosure, covering various aspects such as overall policy development, as well as the assessment of international standards and codes in the IMF/World Bank Financial Sector Assessment Program and the FSB Peer Review program.

The audience for communications on international financial stability policies thus far largely consists of policymakers, market participants, academics, and other experts. It does not appear that there is much awareness of these activities among the broader public. Further consideration could thus be given to which aspects of global financial stability policy initiatives would be of interest to a wider audience, and how the key points could be communicated.

\footnotetext{
${ }^{6}$ FSB Chair Randal K. Quarles has argued that "we must improve our outreach and transparency - including to our membership, other global authorities, the public, and key stakeholders" (Quarles 2019).
} 


\section{Box 3. Bank of England-Communications on Financial Stability}

The Bank of England (BoE) offers an example of advanced good practices in communicating financial stability policies, with an essentially complete range of communications tools covering the full policymaking cycle. The quality and depth of the BoE's financial stability communications is commensurate with its responsibilities for the stability of the world's largest international financial center.

- Financial stability strategy. The BoE publishes a detailed strategy in its annual report. The strategy covers guiding principles, details the approach used to deliver financial stability, and discusses the organizational setup.

- Summary of financial stability policies. The BoE publishes a short but encompassing summary of its overall approach to financial stability, covering the tasks and powers of the Financial Policy Committee (FPC), the rate of the countercyclical capital buffer (a key macroprudential tool), resolution of failed institutions, and regulation and supervision. This makes it easier for nonexpert audiences to understand the BoE's approach.

- Financial stability report. The semiannual FSR is the BoE's flagship communications product on financial stability. It provides an assessment of systemic risks and policies to address them, and also includes stress test results. An impactful graphical presentation summarizes the most important points for the media and public. The FSR is presented by the governor at a press conference, with published opening remarks and a transcript.

- Record and summary of FPC meetings. These records are released with a very short lag of one week. They open with a summary of the discussions, again with an effective use of graphics to convey the main risks and actions. This is followed by more detailed information on the issues covered by the FPC, and an annex summarizing previous policy decisions and their implementation.

- News releases. A dedicated section of the website covers prudential policies. The news releases provide a short and clear summary of actions and analysis, with links to detailed background information.

- Guidance for FPC members. Published guidance notes cover communications by FPC members and the avoidance of conflicts of interest. 



\section{Chapter}

\section{Communications to Support Fiscal}

Fiscal policy can be seen as "the matter of who gets what, when, and how" (Laswell 1936), and as such is intrinsically political (Gaspar, Gupta, and Mulas-Granados 2018). Conflicting interests and views are fundamental in fiscal policy, and not everyone will agree with the decisions taken, regardless of how they are presented.

Nonetheless, disclosure, transparency, and other communications can help to improve the design and implementation of fiscal policy. ${ }^{1}$ Fiscal issues are often intricate and complex, and the public will frequently find it difficult to understand them (Buchanan 1960). At times, it may also be challenging to avoid creating an illusion of transparency focusing on the form ${ }^{2}$ rather than the quality of reporting by governments. By providing clearer and more accessible information on fiscal policy, and engaging citizens, communications can help improve the quality of disclosure ${ }^{3}$ and build public understanding and support, including for fiscal consolidation or deeper reforms.

\section{Communications to Support Public Participation in the Budget Process}

Many countries have been making efforts to enhance the quality of fiscal policy by combining transparency with greater public participation, aided by advances in "digital government" (IMF 2018c) and in communications

\footnotetext{
${ }^{1}$ This section focuses on communications by the government agencies such as ministries of finance and tax offices. Communications by other parties in the fiscal policy debate is beyond the scope of the discussion.

${ }^{2}$ Examples include publishing only partial information; publishing information that is difficult to understand, such as large and detailed amount of data without an explanatory summary; and exploiting weaknesses in accounting and reporting rules. The IMF's Fiscal Transparency Code provides a unified framework for making improvements (IMF 2019a).

3The IMF's April 2019 Fiscal Monitor offers some insights on how to use communications to fight corruption (IMF 2019b).
} 
Figure 3. Communications and Public Participation in the Budget Process

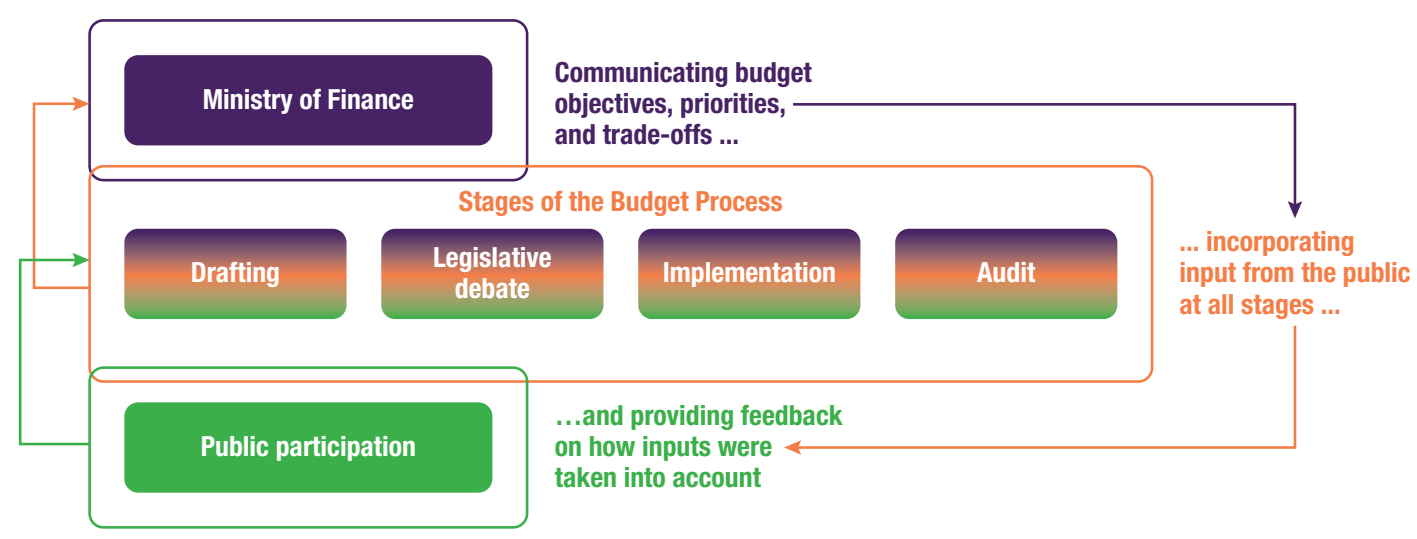

Source: IMF staff.

technologies. Increased public participation in the budget process can support the roles of the executive and legislative branches of government, and audit institutions (IMF 2018a). There is evidence that political budget cycles (with additional spending in the runup to elections) are more pronounced in countries where the public cannot effectively monitor fiscal policies (Shi and Svensson 2006).

Communications can support public engagement at all stages of the budget process — drafting, legislative debate, implementation, and audit (Figure 3). Communications can help by drawing attention to opportunities for public participation, explaining the objective of each engagement (for example, providing information to the public or obtaining comments from the public), and how the inputs provided were taken into account in reaching budget decisions. Increased clarity can also help to manage the public's expectations and support greater realism about fiscal policy.

Communications can support all forms of public participation, such as presenting a citizen's guide to the budget in a more accessible form, using plain language and infographics; web-streaming or televising public hearings or consultations; facilitating online discussions or written submissions; or even providing information on referenda (see Box 4 for a discussion of public participation in budgeting). Machine learning and big data techniques can help to evaluate a large mass of information by identifying key trends and pressing issues.

Communications can also signal that a central goal of fiscal policy is to improve public well-being. This message will be more credible if accompanied by information on how the interests of the public have been taken into 
account in reaching fiscal policy decisions or by regularly reporting on key issues of concern to the public, such as the quality of infrastructure or tax simplification.

Public engagement can also be used to explain and discuss key tradeoffs, such as different options for raising revenue (value added tax vs. corporate tax vs. income tax), or for the design of the social safety net, or the tradeoffs between maintaining transfer spending at the expense of infrastructure investment and a well-functioning public administration.

Enhanced public awareness and greater realism about fiscal policies may be vital when fiscal consolidation is needed. Fiscal consolidation may become necessary unexpectedly when an economy is hit by significant external shocks. Painful measures, involving also significant distributional effects, may need to be taken under time pressure that does not allow for a full public discussion. Communications can build on greater awareness of the need for sustainable public finances achieved through public participation during normal times. Given that fiscal consolidation will typically have "winners" and "losers", communications will need to convincingly argue for the specific mix of measures adopted, and how the most vulnerable groups are being protected.

\section{Communicating Fiscal Rules}

Fiscal rules are used to contain fiscal policy discretion and promote fiscal discipline. They aim to commit policymakers to fiscal discipline and debt sustainability, and anchor expectations.

Communications could raise public understanding of fiscal rules, and thus support their adoption and sustainable implementation. Communications need to clearly explain the ultimate objectives, the role of quantitative indicators (for example, is the budget deficit the ceiling or the target), and the truly binding elements of the framework (Eyraud and others 2018). For example, the three percent deficit rule in the euro area was meant to be a limit on the maximum deficit over the cycle. However, many member states remained close to the ceiling even in good times, and it took only a mild downturn to generate deficits in excess of the limit. As countries began to challenge the Stability and Growth Pact (SGP) in 2003, the credibility of the fiscal rule was also put into question. In many cases, establishing independent fiscal councils may help to make both the rules and the associated communications more credible. Fiscal councils can only be a powerful tool, however, if they are given the authority to independently and regularly report their findings to the public. 


\section{Communicating Deeper Reforms to the Structure of the Public Finances}

Deeper fiscal reforms pose acute communications challenges. Such reforms include, for example, reductions in industrial, agricultural, or energy subsidies; reforms in pension or health care systems; and large-scale tax reform. Some types of reforms are needed mainly in advanced economies (for example, pension or health care reforms), whereas others are more typical in emerging market or low-income countries (for example, energy subsidies). ${ }^{4}$ These reforms often have a direct impact on people's lives, so informing them about policy changes in advance is a task for the government. The way in which reforms are communicated also depends on the scale of their impact (entire population vs. specific groups), sequencing, and time horizon. The communications issues that arise in deeper fiscal reforms are closely related to those in other types of structural reforms (see Box 5).

Although communications are crucial to gaining support for needed reforms in all cases, the specific challenges will differ across countries. Advanced economies will be able to devote greater resources to strategic communications campaigns, media are more developed, and public awareness of economic policy may be higher. Emerging markets and developing economies may face tighter resource constraints, a thinner media, and possibly a public with less access to information. Considerable attention has been given to studying the experience of communications campaigns by organizations such as Organisation for Economic Co-operation and Development (OECD) and World Bank. The issues involved are illustrated here for two common types of reform: energy subsidies and old-age pensions.

\section{Pension Reform-The Role of Public Information}

Reforms to achieve a sustainable public pension system are a high priority in many parts of the world, where rising life expectancy and a larger share of older people is raising the tax burden on the working age population. Pension reforms may include an increase in the retirement age, dampening the growth of benefits, or a shift from defined benefit to defined contribution scheme. The latter may be particularly challenging as empirical studies show that people generally do not save enough for retirement unless forced to do so (Ghilarducci and James 2018), and as a result many people are financially unprepared for old age. ${ }^{5}$

\footnotetext{
${ }^{4}$ The IMF has developed recommendations for priority structural reforms for various groups of countries (IMF 2015a).

${ }^{5}$ Larry Fink, CEO of BlackRock recently noted that "For millions, the prospect of a secure retirement is slipping further and further away-especially among workers with less education, whose job security is increasingly
} 
A communications campaign can help to raise awareness and educate the public about the need to plan and save for retirement, and generally aim to improve financial literacy. However, experience shows that this is not easy. Sometimes the public at large is not interested in the subject (especially the younger generation who see retirement as far off), the policy issues involved are complex, ${ }^{6}$ and the level of financial literacy is often low, especially among the most vulnerable groups (OECD 2013). Ongoing educational campaigns would be needed to achieve lasting effects, including through schools, which can complement (or be coordinated with) the financial literacy campaigns increasingly being undertaken by central banks. However, there are limits in this field to what such campaigns can achieve-and much depends on the policy changes being proposed.

\section{Reform of Energy Subsidies-The Role of Communications Campaigns}

Energy subsidies often impose an unsustainable burden on the public finances; in many cases they are not targeted at those who need them most, and they encourage wasteful use of energy. Even so, reducing or eliminating them is difficult and unpopular, because the immediate effect is higher energy costs for consumers or businesses. In a number of countries, proposals for energy subsidies reform have triggered large-scale protests, and in some cases have led to the resignation of the government or reversal of the reform. ${ }^{7}$

As well as careful implementation and sequencing, a strong communications campaign is one of the most important elements of a successful reform of energy subsidies, as documented in many studies of the political economy of these reforms (World Bank 2012). Surveys show that the public is often unaware of the existence of the subsidies and their effects. A key objective of communications is to educate the public about the costs of the subsidies, the benefits that the reform will bring, and to explain how the most vulnerable groups will be protected. In some cases, the public was largely unaware of the

tenuous. I believe these trends are a major source of the anxiety and polarization that we see across the world today" (Fink 2018).

${ }^{6}$ Retirement savings reform straddles many areas of policy. Possible issues include changes to the tax system to encourage retirement savings, arrangements for insuring against longevity risks, making retirement savings plans portable, measuring and stabilizing the cost of living for the elderly, and consumer protection in financial services.

${ }^{7}$ In Haiti, for example, the government had to announce a plan to eliminate energy subsidies in 2018 without a prior public information campaign to explain the costs of subsidies for the economy, the benefits the reform would bring, and how the most vulnerable would be protected. Protests and riots erupted following the announcement, the reform was suspended, and the prime minister resigned. 
availability of a social protection program, and an important task of communications was to ensure that this information reaches its intended audience. ${ }^{8}$

Even where the public recognizes the inefficiency of energy subsidies, it may have little confidence that the government will use the savings from the reform wisely. This is especially true in countries with a history of widespread corruption, lack of transparency in public policy, and perceived inefficiencies in public spending (Clements and others 2013). A particular challenge is that countries where energy subsidy reforms are most needed may not have sufficient capacity or resources to mount an effective communications campaign. In such cases, a portion of international development aid could be allocated to support public communication of the reform.

\section{Box 4. Public Participation in the Budgetary Process}

Brazil was a pioneer in public participation in the budget process (or participatory budgeting), starting in the late 1980s. Over 100 cities have sought public engagement in budget decisions. Citizens would meet in a townhall format and elect delegates to negotiate the budget. While this process has become well established in local government, the challenges involved in scaling it up to the state level are considerable (Schneider and Goldfrank 2002). Various arrangements for public participation in the budget process have by now spread throughout Latin America. In many countries, it is now required by law to consult civil society organizations on budget priorities. Over time, public participation has become a "best practice" in fiscal policy, and organizations such as OECD and the Global Initiative for Fiscal Transparency are developing guidelines and sharing country experiences. The OECD has also developed methodologies for the evaluation of practices for public participation in policymaking more broadly (OECD 2005).

\footnotetext{
${ }^{8}$ In Ukraine, a survey some months after gas tariffs were increased showed that the public was largely unaware of the social protection scheme introduced to support the most vulnerable groups, or of the options to reduce their gas consumption. Almost 70 percent of respondents thought the resulting energy price increases were not justified. The World Bank worked with the government to enhance the communications campaign, which helped to raise the enrollment in support programs from 1.25 to 5.5 million households (Worley, Pasquier, and Canpolat 2018).
} 


\section{Box 5. Communicating Structural Reforms}

\section{We all know what to do, we just don't know how to get re-elected after weve done it. \\ Jean-Claude Juncker, Prime Minister of Luxemburg and Chairman of the Eurogroup, 2007}

Structural reforms can produce large medium- and long-term gains in economic welfare, but they can also inflict significant short-term pain; and the distribution of gains and losses can also be uneven. The communications challenges are accordingly great.

Structural policies cover a vast domain, including technology and innovation policies, labor and product market regulation, financial regulation, infrastructure, privatization, and agriculture, often requiring significant changes to laws and regulations. Structural reforms have long been a central element of the G20's strategy for achieving job-rich growth; with over 1,000 reform commitments in their national growth strategies. Institutions such as the FSB, International Energy Agency (IEA), International Labour Organization (ILO), OECD, World Bank, and World Trade Organization (WTO) are involved in various areas of structural policy. The IMF's engagement is tailored to the reforms most relevant for countries' macroeconomic circumstances (IMF 2016, 2015a,b).

Communications on structural reforms share many attributes with communications on deeper fiscal policy reforms and involve building broad and sustained public support for reforms. The role of communications has been more studied in some areas (for example, privatization) and less so in others (for example, labor or product markets). There is still considerable scope for deepening the understanding of the role of communications in supporting structural reforms. An OECD study, for example, covered 20 episodes of structural reforms. The country case studies suggest that communications were important to the success of the reforms in many instances. However, owing to the small sample size, it was not possible to draw strong statistical conclusions (Tompson 2009).

Studies of communications to support privatization show that more successful campaigns were integrated into all stages of the project: (1) defining the key objectives of the authorities' economic reform program, and how the privatization project fits into their strategy; (2) going beyond outreach via TV, radio, and newspapers ads to also make use of assessments of public satisfaction with privatization, especially in infrastructure and public services; and (3) assessing the political and social sustainability of privatization, using opinion surveys and political analysis. Moreover, enhancing transparency and disclosure can help build trust and moderate opposition, making reforms more sustainable socially and politically (Calabrese 2008). 



\section{Chapter}

\section{Communicating in Times of Economic Crisis}

In theory, there is no difference between theory and practice. But in practice, there is.

Attributed to Jan L. A. van de Snepscheut, scientist and educator

Numerous countries have experienced economic crises, which may stem from fiscal, financial sector, balance of payments vulnerabilities, or from a combination of factors. Although economic policies will generally aim to avoid crises, the risk of a crisis can only be reduced and not eliminated. Knowing what to say when a crisis strikes can be just as important as knowing what to do. Each crisis is, and will be, different and there are no silver bullets on communications. Still, some general good practices on crisis communications have emerged. More effective communications, based on an ex-ante protocol on who speaks when and about what, can reduce the severity of the crisis and allow for a more rapid recovery, thus reducing the overall costs.

The policy response to a crisis will often involve changes in multiple policies: monetary, fiscal, financial, structural. Communications on economic policies are likely to intensify during a crisis and its aftermath (Figure 4).

Communications cover each field of policy, drawing on established good practices, and also with mutually supportive messages across policy areas. ${ }^{1} \mathrm{~A}$ coordinated approach to communications can help to maintain confidence and reduce the ultimate costs of the crisis (Figure 5).

${ }^{1}$ ECB President Mario Draghi has noted that approximately one third of all speeches by various members of the ECB Executive Board include a reference to structural reforms: "if we talk often about structural reforms it is because we know that our ability to bring about a lasting return of stability and prosperity does not rely only on cyclical policies - including monetary policy - but also on structural policies" (Draghi 2015). Some studies also show that financial crises have intensified central bank communications on fiscal policies, with a focus on the government deficit ratio in the euro area, the United States, and Japan (Allard and others 2013). 
Figure 4. Public Communications on Economic Policies Intensified during the 2008-09 Crisis
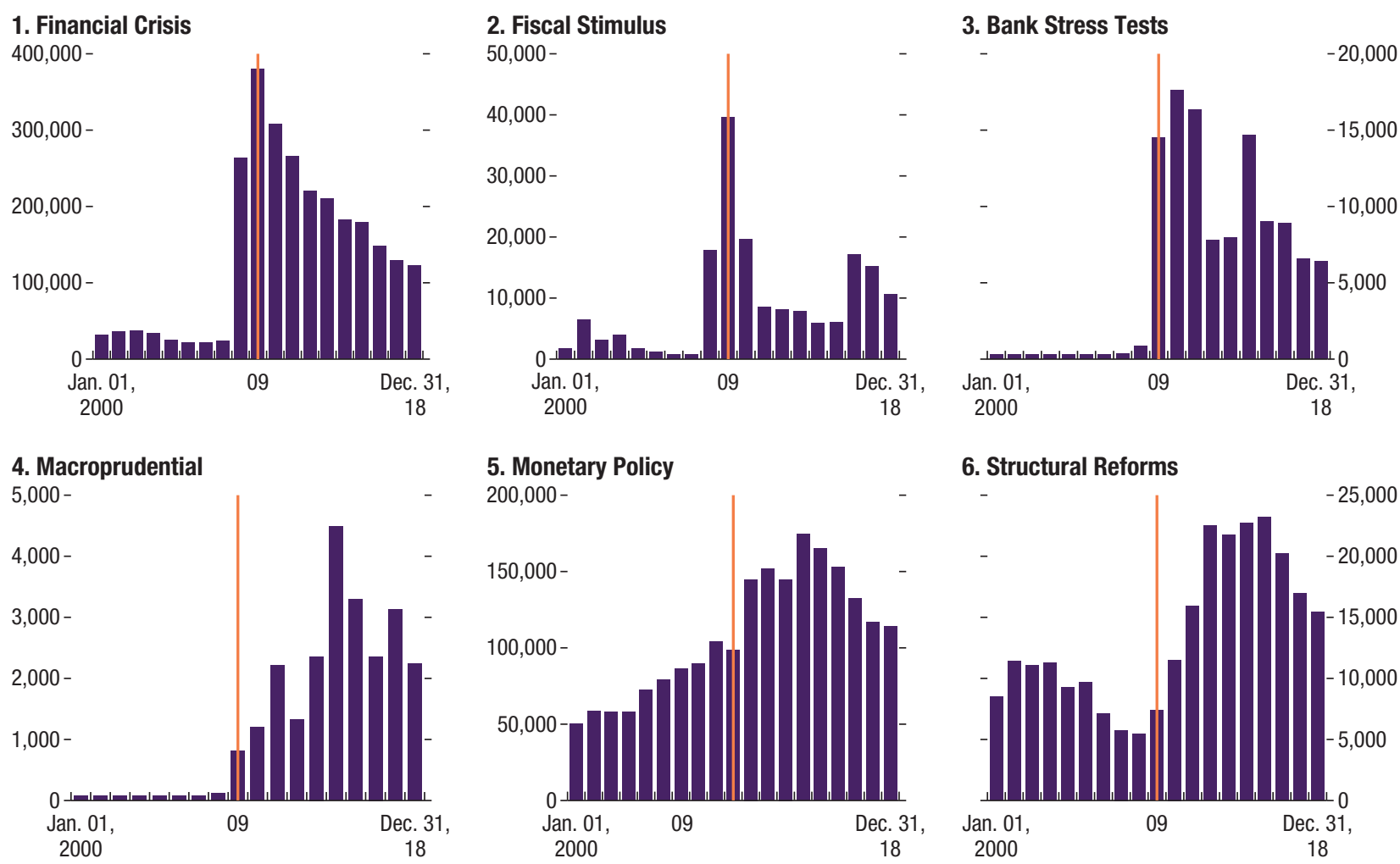

6. Structural Reforms

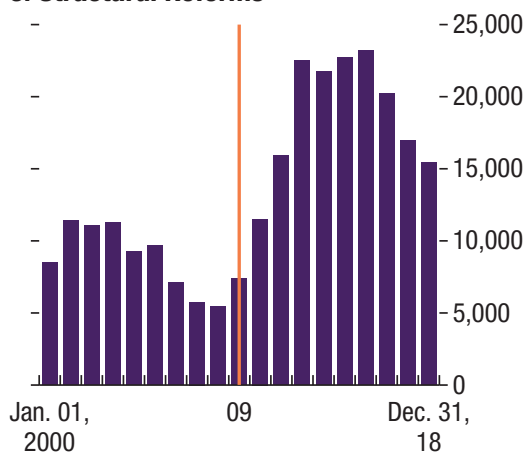

Source: Factiva. The figure shows the number of media reports found for each of the six search phrases.

Figure 5. Mutually Supportive Messages Across Economic Policy Areas

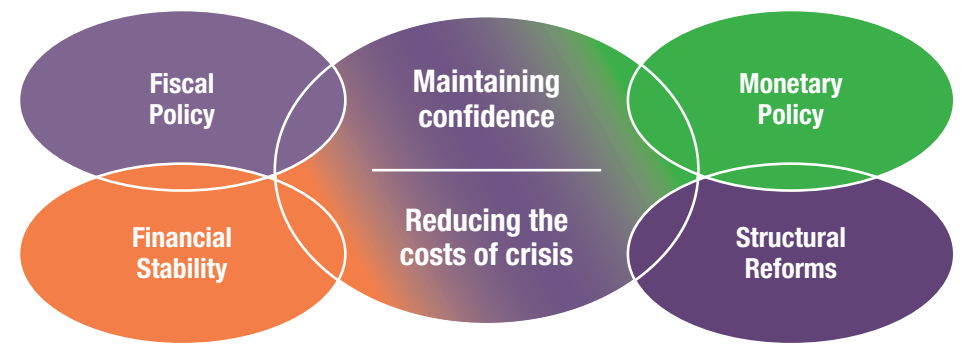

Source: IMF staff. 


\section{Communicating the Assessment of a Crisis}

It is often impossible to immediately assess the scale and depth of a crisis as it develops. For example, it may not be clear at the outset of a crisis whether banks are suffering temporary liquidity shortages or deeper solvency problems. Public messaging about the likely severity of the crisis needs to hit the mark, as mistakes can be destabilizing.

Acknowledging the worst case can sometimes help to restore confidence if accompanied by decisive action. In 2008, for example, then U.S. Treasury Secretary Paulson publicly recognized that the U.S. banking system might be facing major solvency problems, and asked for a staggering $\$ 700$ billion to support bank rescues and restructuring. Ultimately, the amount disbursed was less than $\$ 450$ billion, and most or all of that was recouped through repayments and profits made by the Treasury from reselling bank equity acquired at a low price. By contrast, underestimating and understating the risks may not be helpful.

\section{Restoring Confidence}

At times a single well-targeted message can accomplish much. One well-known example is ECB President Mario Draghi's pledge at the height of the euro area crisis in 2012 to do "whatever it takes" to preserve the Euro. Following this reassurance, market conditions calmed, and financial confidence was restored. The experience of Russia in 2014 provides another example of how communications can play a crucial role in stabilizing expectations (Box 6).

Visuals are also important. When the financial crisis hit Norway, the government and the Norges Bank held a joint press conference to reassure the public that they were working together. This was a powerful signal and helped to restore confidence, and an illustration of the old adage that a picture can say more than a thousand words.

\section{Recovering from Crisis ...}

Communications during the recovery phase, after the crisis has peaked, often receive less attention, but are very important. As the banking crisis in Ireland unfolded, the government announced a comprehensive bank guarantee in September 2008, which prevented a financial collapse but later led to a large increase in public debt, as senior bank bondholders had to be protected. In addition to decisive policy action, the authorities also owned up to the policy mistakes that had led to the crisis (including through the publication in 
2010 of a detailed report prepared by outside experts (Regling and Watson 2010), and laid out comprehensive policies for a return to economic growth. Although these measures and messages were unpopular, they laid the foundation for a robust economic recovery from 2011 on.

\section{... and Preparing for the Next Crisis}

Policymakers and their communications staff increasingly see value in developing know-how in crisis communications: what to say, what not to say, and when to communicate. Helpful preparations include (1) considering in advance possible messages and press lines for various audiences; (2) including a communications component in crisis simulations; and (3) forming a crisis response team that includes political, cultural, behavioral, legal, and communications experts.

Crisis simulation exercises increasingly include a communications component. In January 2019, the Nordic-Baltic Stability Group (NBSG) ${ }^{2}$ held its first exercise to gauge how various agencies_central banks, ministries of finance, and supervisory and resolution authorities-could collectively respond to a financial crisis, in view of the greater interdependence of financial institutions in the region (the IMF attended as an observer). The Group agreed to "exchange information in case of market turbulence affecting cross-border financial stability in the region and, if deemed appropriate, help to coordinate public statements relating to such circumstances" (NBSG 2018). This exercise enabled the participants to test their crisis communications and coordination procedures and prepared them to better "think on their feet" and speak with one voice in a real crisis.

${ }^{2}$ Denmark, Estonia, Finland, Iceland, Latvia, Lithuania, Norway, and Sweden. 


\section{Box 6. Russia-Crisis Response and Communications}

By late 2014, Russia was suffering from the combined effects of sharply falling oil prices and Western sanctions. There was strong downward pressure on the Russian ruble, and banks and corporates came under increasing stress.

The authorities quickly put in place a comprehensive package of stabilization measures, including capital and liquidity support and a sharp increase in the monetary policy rate. To better absorb external shocks and facilitate the adjustment of the balance of payments, the Central Bank of Russia also brought forward the planned transition to a floating exchange rate and the implementation of full-fledged inflation targeting, based on preparations that had been in progress since the 2008-09 crisis.

The central bank was in the lead on communications but benefited from vocal backing from the government. Bank of Russia governor Elvira Nabiullina explained how decisive measures helped avoid a deeper crisis. At the same time, she made clear that the economy would need to adapt to a "new reality," underscoring the need for continuing adjustment. The central bank also accelerated the restructuring of the banking system, by closing more than 400 banks over the next few years.

The central bank has adopted an enhanced communications strategy to reach not only markets and experts but also the general public, in order to build a broad support for their policies. This combination of strong action and skillful communications helped to stabilize the economy and the financial system. These issues were discussed by Governor Nabiullina in her Camdessus Lecture at the IMF (Nabiullina 2018) and in an interview with Finance or Development (Nabiullina 2019). 



\section{Chapter}

\section{(1) Restoring Trust-Why Does It Matter?}

Truth is the most valuable thing we have. Let us economize it. Mark Twain, Following the Equator, 1897

Repeated crises and policy failures have undermined trust in institutions and experts and may have contributed to the rise of populist political movements in some countries. ${ }^{1}$ Cross-country polls conducted by the Pew Research Center and Edelman, among others, show a long-running and deepening decline in trust in institutions in many countries (Figure 6). ${ }^{2}$ The deeper roots of declining trust are not fully understood. The profound effects of the global financial crisis, increasing inequality, unkept promises, political polarization, the capture of political systems and economic gains by small groups, and a lack of sincere attention to the "real economy" needs of the public all seem to have contributed.

\section{Why Trust Is Important}

Trust matters for the success of public policies that depend on collaboration by the public. A lack of trust in institutions can undermine cooperation and compliance by the public with government policies and regulations. Reduced consumer and investor trust can affect economic choices. Trust is a key ingredient of economic growth and societal well-being (Figure 7). Empirical evi-

\footnotetext{
${ }^{1}$ Addressing the UN General Assembly in September 2018, UN Secretary-General Antonio Guterres opened the meeting by saying that the world is "suffering from a bad case of Trust Deficit Disorder" and "people are losing faith in political establishments, polarization is on the rise and populism is on the march" (Guterres 2018).

${ }^{2}$ Measuring trust has pitfalls, and cross-country comparisons can be difficult. However, the decline in trust is by now well-established; and the OECD has developed detailed guidelines for measuring trust (OECD 2017a).
} 
Figure 6. Trust in Institutions Has Declined

1. Average Trust in Institutions, General Population, 2019

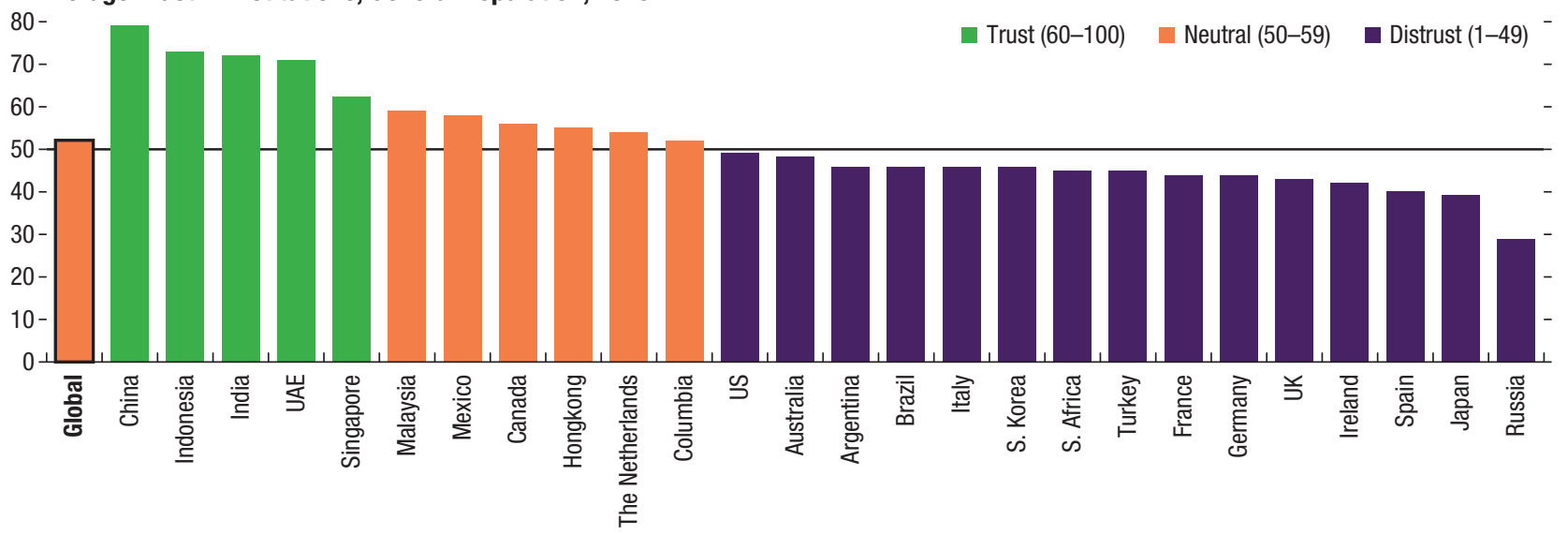

2. Average Trust in Institutions, Informed Population, 2019

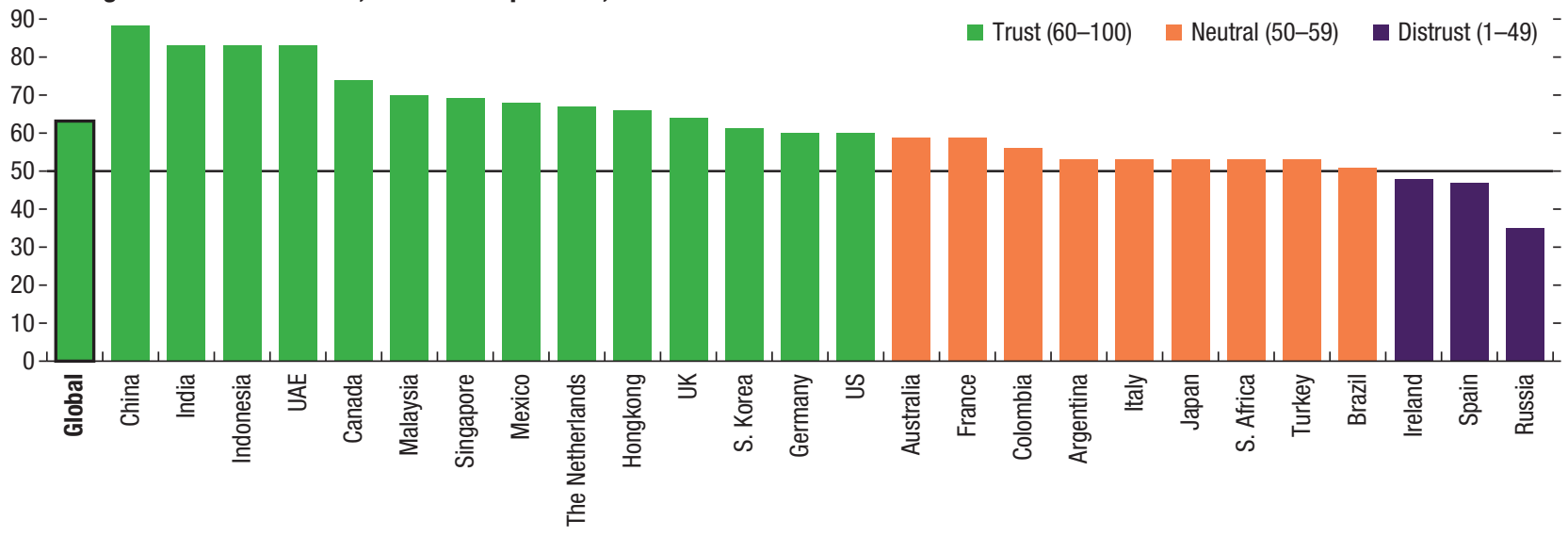

Source: 2019 Edelman Trust Barometer.

dence suggests that, in some countries, restoring social trust and confidence in government can even have much stronger positive effects on well-being than higher per capita incomes (Sachs 2017).

\section{Restoring Trust}

There is a growing recognition of the need to restore trust. For example, the OECD has initiated a Trust Strategy to provide information and guidance to policymakers (OECD 2014). Areas covered include methodologies for measuring trust, along with a citizen-oriented perspective to help restore trust in public institutions (OECD 2017a). 
Figure 7. Generalized Trust and Life Satisfaction in European Countries, 2002-14

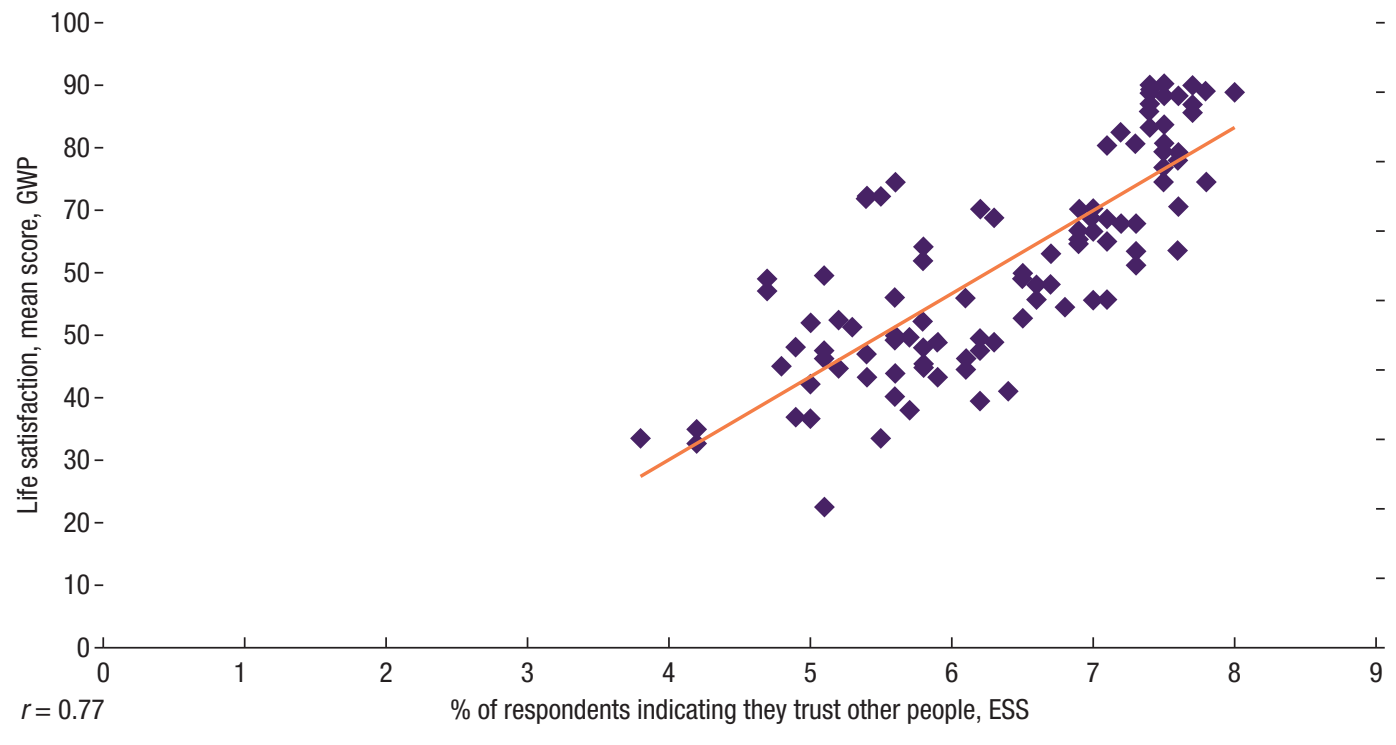

Source: OECD (2017a).

Restoring trust is challenging. "Trust is not a thing that one can literally build, break, and then rebuild. Policymakers cannot simply approve a policy and a budget to rebuild trust in the way they rebuild worn-out infrastructure" (Duncan 2018). In order to be trusted one needs to be trustworthy. While some institutions or policies may be more trustworthy than others, a lack of trustworthiness in any policy institution can spill over to others. Efforts to restore trust will fail if they are perceived as just another attempt at manipulation (or "spin" in communications practice) and may instead end up further eroding trust.

\section{Transparency}

Greater transparency and disclosure are often the first port of call in restoring trust. Publicly available information, easily accessed using new technology, can help the public to hold policymakers accountable, which in turn can contribute to restoring trust. For example, in fiscal policy, a lack of disclosure can undermine accountability and provide opportunities for the misappropriation of public funds. But transparency may also develop dynamics that can further erode trust: "when government information is designed to be disclosed to the public, its value as information stands in decline and its value as an instrument of manipulating the public increases" (Krastev 2018). 


\section{More Direct Public Participation}

New communication technologies enable a more participatory approach to policymaking. There may be a growing expectation among the public that they should be able to provide direct input into policy decisions, and see this input reflected in outcomes. There are some positive examples. In the American city of Boston, the local government has deployed a mobile application to allow citizens to report infrastructure needing repair, which also sends pictures of the repair to those who made the report (Guay 2017). Encouraging participation, like other efforts to restore trust, can be a double-edged sword and further undermine trust if the wishes expressed by the broader public are ignored, including in favor of powerful special interests.

\section{Opinion Polls}

Public opinion polling is another useful tool but can also cut both ways. Opinion polls provide constant and almost instant feedback on the views of the public. When this information leads policy to better reflect public opinion, it can help restore trust. However, incessant polling may encourage short-termism among policymakers (Grattan 2018). It may also lead politicians to engage in a "permanent campaign" that distracts them from governing and from devoting enough time to considering policy decisions (Ornstein and Mann 2000). Polls can also be commissioned by special interest groups to justify their positions, giving rise to misleading "junk polling." While polling can be a useful tool for economic policy institutions to gauge public opinion, its misuse can undermine trust. Digital sentiment analysis offers an alternative to polling, including through opinion mining.

\section{Better Communications}

Good policies are a prerequisite to restoring trust, but good communications are also important. Honesty in communications is fundamental (Box 7). Many widespread and entrenched habits in communications have contributed to a public perception that everything is "spin": empty phraseology, avoiding the issues, appealing to emotion, framing, and not accepting responsibility (Heclo 2008). Work to enable better informed press coverage can also help to restore trust and legitimacy, including by providing journalists with proper information and context (helping them to better understand the issues and report more accurately) and organizational support of communications, along with sufficient resources (Liu, Horsley, and Yang 2012). 


\section{Box 7. Principles for Public Communications in the Netherlands}

The government of the Netherlands has established principles for public communications that may help to restore trust. A stated aim is to ensure that the public has broad trust in official statements and other central government communications. Among other things, communications must be focused on the content of policy, not on image-building for individual members of government, nor should government communications be used for party politics. All government communications need to be recognizable as such, and be factual, straightforward, and accurate. Participation by the public should be explained in advance, including the way in which public inputs are expected to be used. Citizen questions and complaints can be transmitted through the channel of the citizen's choosing and require a swift and appropriate official response.

Source: Government of the Netherlands, The Principles of Government Communications, 2017. 



\section{Chapter}

\section{Building Communications Capacity}

... one of the signs of a healthy civilization is the existence of a relatively clear language in which everyone can participate in their own way. The sign of a sick civilization is the growth of an obscure, closed language that seeks to prevent communication.

John Ralston Saul, The Unconscious Civilization, 1995

To address the challenges of the new information environment, economic policy institutions will need to continue strengthening their communications capacity. A contemporary full-fledged communications unit needs to engage with various audiences, with different degrees of sophistication, using multiple channels and a variety of formats. ${ }^{1}$ Practice also shows that to be more effective and strategic, communications need to be increasingly integrated with operations, drawing on an in-depth understanding of policies and their future path.

Simpler language is key for reaching a broader audience. Some areas of economic policy are seeing an increasing complexity of language, including through newly created jargon and acronyms, which may not always be justified by the intrinsic complexity of the policy issues, and may not be comprehensible even to informed readers who are not specialists in the field. This creates a barrier to an open public debate. One objective is to find ways to simplify language - without changing the meaning - to facilitate a better understanding of policies across a range of audiences. ${ }^{2}$

Communications will need to be more innovative, harnessing new technologies and techniques, while being guided by ethics. Success will to a large

\footnotetext{
${ }^{1}$ Such as social media, blogs, videos, and podcasts, in addition press conferences, interviews, and speeches.

${ }^{2}$ Andy Haldane of the Bank of England has suggested that the main monetary policy messages for the general public should be drafted by the members of the Monetary Policy Committee (Haldane 2017a).
} 
Figure 8. Communications Tiered by Content and Channels

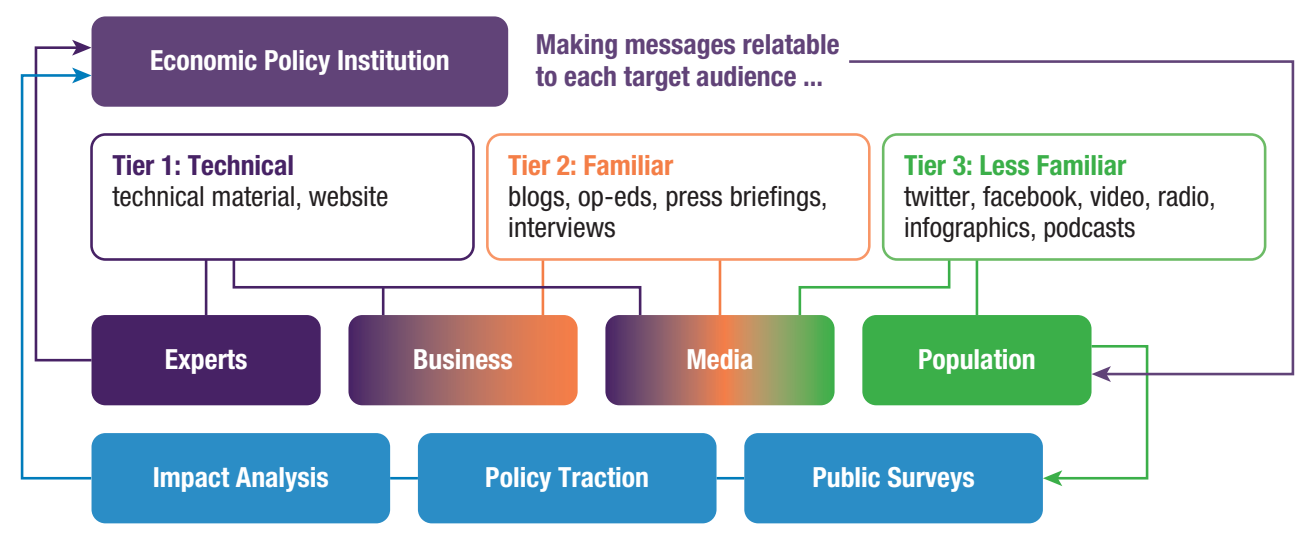

Source: IMF staff.

extent depend on the understanding of the how and why of communications, the ability to deliver tiered ${ }^{3}$ and relatable messages, and make use of behavioral insights drawn from psychology and cognitive and social science (OECD 2017b) — while being mindful of the need to raise standards for integrity and trustworthiness. Indeed, techniques that are coming into widespread use (see below) have ethical implications (Barnett and Mahony 2011), and need to be applied in an ethical manner.

- Tiering (or layering) of messages applies both to content and to channels. Tiering by content means that the same core message is provided at two or three levels of technicality (Figure 8). Recipients would then be able to choose the format that is most meaningful to them. Tiering by channels means that the same message is adapted to and sent via print, television, radio, video, online, and social media to reach all tiers of recipients (sometimes referred to as channel declination).

- Audience segmentation. Different audience groups have different characteristics, and they influence the extent to which people pay attention to, understand, and act on different messages. Some types of audience segmentation are necessary and indeed unavoidable (such as communicating in different languages).

- More relatable messages. It is vital to make messages relatable, adapting the content to the interests of the audiences they are trying to reach. ${ }^{4}$ The average consumer, for example, may be interested mainly in the purchasing

\footnotetext{
${ }^{3}$ The Reserve Bank of New Zealand, for example, publishes the monetary policy statement in pictures.

${ }^{4}$ On the concept of relatability, see Bank of England's paper on Enhancing Central Bank Communications with Behavioural Insights. A key finding was that relatability improved public understanding compared to the traditional Monetary Policy Summary.
} 
power of his personal earnings and savings, and wants to be reassured that the central bank is keeping inflation low. Finance professionals will want to know how the central bank arrived at its decision, in order to cross-check this information with their own analysis and projections of interest rates, inflation, and economic outlook.

- An analytical capacity to conduct deeper impact assessments is also important. For communications focusing on economic policies, it is important to understand whether policy messages had traction with the targeted audiences, and whether the messages were believed and trusted. Quantitative and qualitative analysis, including opinion surveys, can help to inform communications strategy and practice, and adjust allocation of resources.

More international sharing of experiences in economic policy communications would be beneficial. International professional associations of communicators, conferences, and workshops organized to learn about other institutions' and countries' innovative ideas and experiences can support faster progress in capacity building and adopting up-to-date communications practices. ${ }^{5}$ International organizations have been involved in supporting capacity building in communications and continue to contribute to these efforts. ${ }^{6}$

\footnotetext{
${ }^{5}$ One example is the ECB conference on Communications: Challenges for Policy Effectiveness, Accountability and Reputation, held in 2017.

${ }^{6}$ For example, joint work by the IMF, Norges Bank, and the Bank of Mozambique to strengthen Bank of Mozambique's financial stability communications.
} 



\title{
Conclusion-What Does the Future Hold for Economic Policy Communications?
}

\author{
... perché sempre una mutazione lascia lo addentellato per la \\ edificazione dell'altra \\ (... for one change always leaves a dovetail into which another will fit) \\ Niccolo Machiavelli, The Prince, Chapter II, 1532
}

The frontier is open, with new communications challenges continuing to emerge in all fields of economic policy. Increasingly, across all economic policy areas and political systems, communications need to reach and convince a broader audience, and be able to quickly counteract misinformation.

Approaches to economic policy communications differ across areas of policy, and across countries - there are no one-size-fits-all solutions. In some areas, communications are already an integral part of a well-established policy framework (inflation targeting). In others, the policy frameworks are still developing and so are communications (financial stability); and, in some areas, communications blend into politics (fiscal and structural policies). There is room for each area of policy to draw on experiences in the others. A country's history and traditions have a profound influence on how economic policies are communicated, as so does the quality of economic media.

Even so, the design of communications can always take place within a common framework covering objectives, communicators, messages, audiences, channels and formats, and impact assessments. This framework is likely to remain valid and provides a sound basis for developing more effective communications strategies, tactics, activities, and products. It can be used across many economic policy areas and countries.

Maintaining or restoring trust will likely be one of the central challenges for communications in coming years. Progress in this area will require not 
just sound economic policies, but also adherence to good communications principles such as transparency, clarity, consistency, precision, and timeliness. Principled and honest communications can help build and maintain confidence in policies at any stage: when the policy framework is being developed or modified, when new initiatives or reforms are envisaged, and when policy is being implemented.

The rise of digital and social media has fundamentally altered the landscape, and the communications toolkit will continue to adapt to these ongoing changes. The understanding of the hows and whys of communications is likely to continue to deepen in coming years. Finding innovative solutions, better addressing key audiences, and applying new techniques are likely to become defining factors for success.

International sharing of experiences will continue to be beneficial. Change will be the only constant in strengthening institutional communications capacity, and the experience of other countries and institutions can provide valuable insights.

Building understanding of policy is, in itself, fundamental to policy effectiveness. So, the point is not communications for its own sake but for policy efficacy. There is no going back. 


\section{References}

Aldasoro, I., C. Borio, and M. Drehmann. 2018. "Early Warning Indicators of Banking Crises: Expanding the Family.” BIS Quarterly Review (March).

Allard, J., M. Catenaro, J. Vidal, and G. Wolswiik. 2013. "Central Bank Communication on Fiscal Policy.” Working Paper Series 1477, European Central Bank, Frankfurt.

Al-Mashat, R., K. Clinton, D. Laxton, and H. Wang. 2018. "Transparency and Communications." In Advancing the Frontiers of Monetary Policy, edited by T. Adrian, D. Laxton, and M. Obstfeld. Washington, DC: International Monetary Fund.

Bank for International Settlements (BIS). 2018. BIS Annual Report. Basel.

Bank of Canada. 2018. "Public Awareness and Communications Survey." Ottawa.

Barnett, C. and N. Mahony. 2011. "Segmenting Publics." Economic and Social Research Council. Bristol, UK.

Bernanke, B. 2012. Transcript of Chairman Bernanke's press conference, Washington, DC, January 25. https://www.federalreserve.gov/mediacenter/ files/FOMCpresconf20120125.pdf.

Bholat, D., N. Broughton, A. Parker, J. Ter Meer, and E. Walczak. 2018. "Enhancing Central Bank Communications with Behavioral Insights." Staff Working Paper 750, Bank of England, London.

Blinder, A. S. 2004. The Quiet Revolution in Central Banking Goes Modern. New Haven, CT: Yale University Press.

Born, B., M. Ehrmann, and M. Fratzscher. 2011. "Central Bank Communication on Financial Stability.” Working Paper 1332, European Central Bank, Frankfurt.

Buchanan, J. M. 1960. Fiscal Theory and Political Economy. Chapel Hill, NC: University of North Carolina Press.

Calabrese, D. 2008. "Strategic Communication for Privatization, Public-Private Partnerships, and Private Participation in Infrastructure Projects.” World Bank Working Paper 139, World Bank, Washington, DC.

Central Bank of Nigeria. 2013. "CBN Denies Fake Social Media Accounts," press release, March 26.

Chesney R., and D. Citron. 2019. "Deepfakes and the New Disinformation War.” Foreign Affairs 98 (1): 147-55. 
Clements, B., D. Coady, S. Fabrizio, S. Gupta, T. Alleyne, and C. Sdralevich. 2013. Energy Subsidy Reform. Lessons and Implications. Washington, DC: International Monetary Fund.

Coeuré, B. 2018. "Forward Guidance and Policy Normalization." Speech at the German Institute for Economic Research, Berlin, September 17.

Donnery, S. 2017. "Communication, Calibration and CoordinationChallenges Implementing Macroprudential Policy in the Euro Area." Speech at the Second ECB Macroprudential and Research Conference, Frankfurt, May 12.

Draghi, M. 2015c. "Structural Reforms, Inflation and Monetary Policy." Introductory speech at the ECB Forum on Central Banking, Sintra, Portugal, May 22.

Duncan, G. 2018. "How to Restore Trust in Governments and Institutions." The Conversation, November 8.

Edelman. 2019. Edelman Trust Barometer. Washington, DC.

Edge, R.M. and J.N. Liang. 2019. "New Financial Stability Governance Structures and Central Banks." Hutchins Center on Fiscal and Monetary Policy at Brookings, Hutchins Center Working Paper No. 50.

Eyraud, L., X. Debrun, A. Hodge, V. Lledo, and C. Pattillo. 2018. "Second-Generation Fiscal Rules: Balancing Simplicity, Flexibility, and Enforceability.” IMF Staff Discussion Note 18/04, International Monetary Fund. Washington, DC.

European Systemic Risk Board (ESRB). 2014a. Flagship Report on Macro-prudential Policy in the Banking Sector. Frankfurt.

- 2014b. The ESRB Handbook on Operationalising Macro-prudential Policy in the Banking Sector. Frankfurt.

- 2017. "A Review of Macroprudential Policy in the EU in 2016." Frankfurt.

Fink, L. D. 2018. "An Annual Letter to Shareholders.” In BlackRock Annual Report. New York: BlackRock, Inc.

Gaspar, V., S. Gupta, and C. Mulas-Granados, eds. 2018. Fiscal Politics. Washington, DC: International Monetary Fund.

Gennaioli, N., and A. Shleifer. 2018. A Crisis of Beliefs: Investor Psychology and Financial Fragility. Princeton, NJ: Princeton University Press.

Ghilarducci, T., and T. James. 2018. "Americans Haven't Saved Enough for Retirement. What Are We Going to Do About It?” Harvard Business Review digital, March 28. 
Grattan, M. 2018. "If Politicians Want More Trust from Voters, They Need to Start Behaving with Civility and Respect." The Conversation, June 28.

Guay, J. 2017. “Trust in Government is Falling-Here's How We Can Restore It." Apolitical, December 12.

Guterres, A. 2018. Address to the General Assembly, United Nations. New York, September 25. https://www.un.org/sg/en/content/sg/speeches/2018 -09-25/address-73rd-general-assembly.

Haldane, A. 2017a. "Looking Ahead: What Is on Central Banks' Communication Agenda?" Remarks at the Central Bank Communications Conference on "Communications Challenges for Policy Effectiveness, Accountability and Reputation.” European Central Bank, Frankfurt.

- and M. McMahon. 2018. "Central Bank Communications and the General Public." AEA Papers and Proceedings 108:578-83.

Heclo, H. 2008. Thinking Institutionally. Oxford: Oxford University Press.

Howlett, M. 2009. "Government Communication as a Policy Tool: A Framework for Analysis." Canadian Political Science Review 3 (2).

International Monetary Fund (IMF). 2013. "The Interaction of Monetary Policy and Macroprudential Policies.” Policy Paper, Washington, DC.

- 2014. Staff Guidance Note on Macroprudential Policy, Washington, DC.

_. 2015a. "Structural Reforms and Macroeconomic Performance: Initial Considerations for the Fund.” IMF Staff Report, Washington, DC.

- 2015b. "Structural Reforms and Macroeconomic Performance: Country Cases." IMF Staff Report, Washington, DC.

- 2015c. "Evolving Monetary Policy Frameworks in Low-Income and Other Developing Countries.” IMF Staff Report, Washington, DC.

. 2015d. "Monetary Policy and Financial Stability." IMF Policy Paper, Washington, DC.

—. 2016. "Staff Note for the G20_A Guiding Framework for Structural Reforms," Washington, DC.

- 2018a. Fiscal Transparency Handbook. Washington, DC.

. 2018b. Global Financial Stability Report: A Bumpy Road Ahead. Washington, DC, April.

- 2018c. "Digital Government." In Fiscal Monitor: Capitalizing on Good Times. Washington, DC, April. 
- 2018d. Global Financial Stability Report: A Decade after the Global Financial Crisis: Are We Safer? Washington, DC, October.

- 2019a. Fiscal Transparency Code. Washington, DC.

—. 2019b. Fiscal Monitor: Curbing Corruption. Washington, DC, April.

Krastev, I. 2018. "Does More Transparency Mean More Trust?” In TrustThe Fight to Win It Back. Washington, DC: Open Government Partnership.

Lagarde, C. 2019. “The Financial Sector: Redefining a Broader Sense of Purpose.” 32nd World Traders' Tacitus Lecture, International Monetary Fund, London, February 28.

Lambert, R. 2006. "Central Bank Communications: Best Practices in Advanced Economies." Speech at the IMF Sponsored Regional Seminar on Central Bank Communications, Mumbai, January 23.

Laswell, H. 1936. Politics: Who Gets What, When, How. New York: McGraw-Hill.

Liu, B. F., J. S. Horsley, and K. Yang. 2012. "Overcoming Negative Media Coverage: Does Government Communication Matter?” Published by Oxford University Press on behalf of the Journal of Public Administration Research and Theory.

Lustenberger, T., and E. Rossi. 2017. "Does Central Bank Transparency and Communication Affect Financial and Macroeconomic Forecasts?” Working Paper 2017-12, Swiss National Bank, Zurich.

Morris, S., and H. Shin. 2018. "Central Bank Forward Guidance and the Signal Value of Market Prices.” Working Paper, Bank for International Settlements, Basel.

Nabiullina, E. 2018. "Russia's Rocky Road to the (Inflation) Target." Camdessus Lecture at the International Monetary Fund, Washington, DC, September 6.

- 2019. "Pursuing Stability." Interview in Finance \& Development 56 (1).

Nier, E., and H. Kang. 2016. "Monetary and Macroprudential PoliciesExploring Interactions.” BIS Papers 86, Bank for International Settlements, Basel.

Nordic-Baltic Stability Group (NBSG). 2018. "Memorandum of Understanding on Cooperation and Coordination on Cross-Border Financial Stability between Relevant Ministries, Central Banks, Financial Supervisory Authorities and Resolution Authorities of Denmark, Estonia, Finland, Iceland, Latvia, Lithuania, Norway, and Sweden.” Tallinn, Estonia. 
Obstfeld, M. 2018. Transcript of an interview with Maurice Obstfeld, IMF Economic Counsellor and Director of Research, by a media group, December 4. www.imf.org/en/News/Articles/2018/12/12/tr120418-transcript-of -the-interview-granted-by-maurice-obstfeld.

Organisation for Economic Co-operation and Development (OECD). 2005. Evaluating Public Participation in Policy Making. Paris.

- 2013. Improving Pension Information and Communication. Paris.

- 2014. Towards an OECD Strategy on Trust in Government. Paris.

—. 2017a. OECD Guidelines on Measuring Trust. Paris.

- 2017b. Behavioral Insights and Public Policy: Lessons from around the World. Paris.

Ornstein, N. J., and T. E. Mann, eds. 2000. The Permanent Campaign and Its Future. Washington, DC: American Enterprise Institute and Brookings Institution.

Poloz, S. 2018. "Let Me Be Clear: From Transparency to Trust and Understanding." Remarks before the Greater Victoria Chamber of Commerce, Victoria, British Columbia, June 27.

Quarles, R. K. 2019. "Ideas of Order: Charting a Course for the Financial Stability Board.” Remarks at Bank for International Settlements Special Governors Meeting, Hong Kong, February 10.

Regling, K., and M. Watson. 2010. "A Preliminary Report on the Sources of Ireland's Banking Crisis." Government of Ireland, Dublin.

Sachs, J. D. 2017. "Restoring American Happiness.” In World Happiness Report, edited by J. Helliwell, R. Layard, and J. Sachs. New York: Sustainable Development Solutions Network.

Shi, M., and J. Svensson. 2006. "Political Budget Cycles: Do They Differ across Countries and Why?" Journal of Public Economics 90 (8-9): 1367-89.

Shin, H. 2013. "Procyclicality and the Search for Early Warning Indicators.” IMF Working Paper 13/258, International Monetary Fund, Washington, DC.

Schneider, A. and B. Goldfrank. 2002. "Budgets and Ballots in Brazil: Participatory Budgeting from the City to the State." IDS Working Paper 149, Institute of Development Studies, Brighton, Sussex, England.

Siklos, P. L. 2014. "Communications Challenges for Multi-Tasking Central Banks: Evidence, Implications.” International Finance 17 (1): 77-98. 
Tompson, W. 2009. “The Political Economy of Reform.” In Lessons from Pensions, Product Markets and Labour Markets in Ten OECD Countries. Paris: Organisation for Economic Co-operation and Development.

Wadsworth, A. 2017. "An International Comparison of Inflation-Targeting Frameworks." Reserve Bank of New Zealand Bulletin 80 (8).

Williams, J. C. 2018. Discussion of "Language after Liftoff: Fed Communication away from the Zero Lower Bound." Presentation at US Monetary Policy Forum, New York.

World Bank. 2012. Europe and Central Asia Balancing Act-Cutting Subsidies, Protecting Affordability, and Investing in the Energy Sector in Eastern Europe and Central Asia Region. Report 69447-ECA, Washington, DC.

Worley, H., S. B. Pasquier, and E. Canpolat. 2018. Designing Communication Campaigns for Energy Subsidies Reform: Communications. Energy Subsidy Reform Assessment Framework (ESRAF) Good Practice Note 10, World Bank, Washington, DC.

Yellen, J. 2013. Speech at IMF Rethinking Macro Policy II Conference, Washington, DC, April 16. 


\section{Further Reading}

Adler, R. S., and R. D. Pittle. 1984. "Cajolery or Command: Are Education Campaigns an Adequate Substitute for Regulations?" Yale Journal on Regulation 1 (2): 159-93.

Adrian, T., D. Laxton, and M. Obstfeld, eds. 2018. Advancing the Frontiers of Monetary Policy. Washington, DC: International Monetary Fund.

Adrian, T., and H. S. Shin. 2012. "Procyclical Leverage and Value-At-Risk." Federal Reserve Board of New York Staff Report 338, New York.

Agenor, P., and L. Pereira da Silva. 2019. Integrated Inflation TargetingAnother Perspective from the Developing World. Basel: Bank for International Settlements.

Algan, Y., S. Guriev, E. Papaioannou, and E. Passari. 2017. "The European Trust Crisis and the Rise of Populism." Brookings Papers on Economic Activity, Brookings Institution, Washington, DC.

Amaglobeli, D., H. Chai, E. Dabla-Norris, K. Dybczak, M. Soto, and A. F. Tieman. 2019. "The Future of Saving: The Role of Pension System Design in an Aging World.” IMF Staff Discussion Note 19/01. Washington, DC: International Monetary Fund.

Amamiya, M. 2018. “The Future of Money." Lecture at the Japan Society of Monetary Economics, Tokyo, October 20.

Archer, D., and A. Levin. 2017. "Robust Design Principles for Monetary Policy Committees." In Central Bank Frameworks: Evolution or Revolution? Edited by John Simon and Maxwell Sutton. Conference volume for a joint 2018 Reserve Bank of Australia-Bank for International SettlementsDartmouth conference.

Asmussen, J. 2012. "Building Trust in a World of Unknown UnknownsCentral Bank Communications between Markets and Politics in a Crisis." Speech at the European Commission Summit, Brussels, July 6.

Atkinson, A., D. Harrison, F. Messy, and J. Yermo. 2012. "Lessons from National Pensions Communication Campaigns." OECD Working Papers on Finance, Insurance and Private Pensions 18, Organisation for Economic Co-operation and Development, Paris.

Atkinson, A. 2015. Inequality: What Can Be Done? Cambridge, MA: Harvard University Press.

Banerji, A., V. Crispolti, E. Dabla-Norris, R. Duval, C. Ebeke, D. Furceri, T. Komatsuzaki, and T. Poghosyan. 2017. "Labor and Product Market Reforms in Advanced Economies: Fiscal Costs, Gains, and Sup- 
port.” IMF Staff Discussion Note 17/03, International Monetary Fund, Washington, DC.

Banks, G. 2005. "Structural Reform Australian-Style: Lessons for Others?" Based on a presentation to the International Monetary Fund and World Bank (Washington, DC) and Organisation for Economic Co-operation and Development (Paris), Australian Government, Productivity Commission, Sydney.

Bascand, G. 2013. "Communication, Understanding, and Credibility." Speech to the Admirals Breakfast Club, Auckland, December 6.

Bernanke, B. 2013. "Communication and Monetary Policy." Remarks at the National Economists Club Annual Dinner, Herbert Stein Memorial Lecture, Washington, DC.

- 2014. "Central Banking after the Great Recession: Lessons Learned and Challenges Ahead: A Discussion with Federal Reserve Chairman Ben Bernanke on the Fed's 100th Anniversary." Brookings Institution, Washington, DC.

_ 2017. "Monetary Policy in a New Era." Brookings Institution, paper prepared for the Conference on Rethinking Macroeconomic Policy, Peterson Institute for International Economics, Washington, DC.

- 2018. "Should the Fed Stick with the 2 Percent Inflation Target or Rethink It?” Remarks at a Brookings Institution event, January 8, Washington, DC.

Bernays, E. 1928. Propaganda. New York: Horace Liveright.

Blinder,A.S. 2007. "Monetary Policy by Committee: Why and How?" European Journal of Political Economy 23 (1): 106-23.

_. 2018. "Through a Crystal Ball Darkly: The Future of Monetary Policy Communications.” AEA Papers and Proceedings 108:567-71.

—, M. Ehrmann, M. Fratzscher, J. Haan, and D. Jansen. 2008. “Central Bank Communication and Monetary Policy: A Survey of Theory and Evidence." Journal of Economic Literature (December): 910-45.

Blinder, A. S., C. Goodhart, P. Hildebrand, D. Lipton, and C. Wyplosz. 2001. "How Do Central Banks Talk?" Geneva Reports on the World Economy 3.

Boeri, T., M. Prachi, C. Papageorgiou, and A. Spilimbergo. 2018. "Populism and Civil Society." IMF Working Paper 18/245, International Monetary Fund, Washington, DC. 
Bonfiglioli, A., and G. Gancia. 2017. "Economic Uncertainty and Structural Reforms.” Economic Working Paper 1494, Department of Economics and Business, Universitat Pompeu Fabra, Barcelona.

Born, B., M. Ehrmann, and M. Fratzscher. 2012. "Communicating about Macroprudential Supervision-A New Challenge for Central Banks." International Finance 15 (2): 179-203.

Bouckaert, G. 2012. "Trust and Public Administration.” Administration 60 (1): 91-115.

Campbell, J., C. L. Evans, J. D. M. Fisher, and A. Justiniano. 2012. “Macroeconomic Effects of FOMC Forward Guidance," Brookings Papers on Economic Activity (Spring): 1-54.

Carney, M. 2018a. "Letter to the G20 Leaders." Financial Stability Board, Buenos Aires.

- 2018b. "True Finance-Ten Years after the Financial Crisis." Speech at the Economic Club of New York, October 19.

Carstens, A. 2018. "Deposit Insurance and Financial Stability: Old and New Challenges." Keynote address at the 17th International Association of Deposit Insurers Annual General Meeting and Annual Conference on "Deposit Insurance and Financial Stability: Recent Financial Topics." Basel, October 18.

_. 2019. "The New Role of Central Banks." Speech delivered at the Financial Stability Institute's 20th anniversary conference, "A Cross-Sectoral Reflection on the Past, and Looking Ahead to the Future," Basel, March 12.

Cihák, M., S. Muñoz, S. Teh Sharifuddin, and K. Tintchev. 2012. "Financial Stability Reports: What Are They Good For?” IMF Working Paper 12/1, International Monetary Fund, Washington, DC.

Clinton, K., C. Freedman, M. Juillard, O. Kamenik, D. Laxton, and H. Wang. 2015. "Inflation-Forecast Targeting: Applying the Principle of Transparency." IMF Working Paper 15/132, International Monetary Fund, Washington, DC.

Coenen, G., M. Ehrmann, G. Gaballo, P. Hoffmann, A. Nakov, S. Nardelli, E. Persson, and G. Strasser. 2017. "Communication of Monetary Policy in Unconventional Times," ECB Working Paper 2080, European Central Bank, Frankfurt.

Coeuré, B. 2018. "Central Banking in Times of Complexity." Panel Remarks at a Conference on the Occasion of Sveriges Riksbank's 530th Anniversary, Stockholm, May 25. 
Coibion, O., Y. Gorodnichenko, and M. Weber. 2019. "Monetary Policy Communications and Their Effects on Household Inflation Expectations." NBRB Working Paper 25482, National Bureau of Economic Research, Washington, DC.

Committee on the Global Financial System (CGFS). 2012. "Operationalizing the Selection and Application of Macroprudential Instruments." CGFS Paper 48, Bank for International Settlements, Basel.

- 2016. "Objective-setting and Communication of Macroprudential Policies.” CGFS Paper 57, Bank for International Settlements, Basel.

Corbacho, A., and S. P. Shanaka, eds. 2018. The Asian Way: Sustaining Growth and Stability. Washington, DC: International Monetary Fund.

Da Silva, A. D., A. Givone, and D. Sondermann. 2017. "When Do Countries Implement Structural Reforms?” Working Paper Series 2078, European Central Bank, Frankfurt.

Daude, C., H. Gutiérrez, and A. Melguizo. 2012. "What Drives Tax Morale?” OECD Development Centre Working Paper 315, Organisation for Economic Co-operation and Development, Paris.

De Guindos, L. 2018. "The ECB and Financial Stability." Speech at the joint National Bank of Belgium, Toulouse School of Economics, Solvay Brussels School of Economics and Management, and European Central Bank Colloquium, Brussels, November 5.

De Michelis, A., and M. Iacoviello. 2016. "Raising an Inflation Target: The Japanese Experience with Abenomics.” European Economic Review 88 (C): 67-87.

Deslongchamps, A. 2018. "Readability and the Bank of Canada." Staff Analytical Note No 2018-20. Bank of Canada, Ottawa. June.

Dincer, N., and B. Eichengreen. 2014. "Central Bank Transparency and Independence: Updates and New Measures." International Journal of Central Banking 10 (1): 189-253.

Dorich, J., N. L. St-Pierre, V. Lepetyuk, and R. Mendes. 2018. "Could a Higher Inflation Target Enhance Macroeconomic Stability?” BIS Working Paper 720, Bank for International Settlements, Basel.

Dornbusch, R., and S. Edwards, eds. 1991. The Macroeconomics of Populism in Latin America. Chicago: Chicago University Press.

Draghi, M. 2015a. "Accounts and Accountability." Speech at the Euro50 Group Roundtable Monetary Policy in Times of Turbulence, Frankfurt, March 31. 
. 2015b "The ECB’s Recent Monetary Policy Measures: Effectiveness and Challenges." Camdessus Lecture at the International Monetary Fund, Washington, DC, May 14.

- 2017. "The Interaction between Monetary Policy and Financial Stability in the Euro Area." Speech at the first conference on financial stability organized by Bank of Spain and Centro de Estudios Monetarios y Financieros, Madrid, March 31.

- 2018. "Central Bank Independence." First Lamfalussy Lecture at the National Bank of Belgium, Brussels, October 26.

Dudley, W. 2018. "Important Choices for the Federal Reserve in the Years Ahead.” Remarks at Lehman College, New York, April 18.

Dustmann C., B. Eichengreen, S. Otten, A. Sapir, G. Tabellini, and G. Zoega. 2017. Europe's Trust Deficit. Causes and Remedies. Washington, DC: CEPR Press.

Duval, R., D. Furceri, B. Hu, J. T. Jalles, and H. Nguyen. 2018. "A Narrative Database of Major Labor and Product Market Reforms in Advanced Economies." IMF Working Paper 18/19, International Monetary Fund, Washington, DC.

Feroli, M., D. Greenlaw, P. Hooper, F. Mishkin, and A. Sufi. 2016. "Language after Liftoff: Fed Communication away from the Zero Lower Bound.” Research in Economics 71 (3): 452-90.

Fischer, R. W. 2014a. Remarks before the Asia Society, Hong Kong Center, Hong Kong, April 4.

- 2014b. Remarks before the Louisiana Bankers Association 114th Annual Convention and Expo, New Orleans, May 9.

Fischer, S. 2015. "Central Bank Independence.” Speech at the 2015 Herbert Stein Memorial Lecture National Economists Club, Washington, DC, November 4.

Fisher L., B. Horsley, J. Suzanne, and K. Yang. 2012. "Overcoming Negative Media Coverage: Does Government Communication Matter?” Journal of Public Administration Research and Theory 22 (3): 597-621.

Freedman, C., and D. Laxton. 2009. "IT Framework Design Parameters.” IMF Working Paper 09/87, International Monetary Fund, Washington, DC.

Fuhrer, J., G. Olivei, E. Rosengren, and G. Tootell. 2018. "Should the Fed Regularly Evaluate Its Monetary Policy Framework?” Brookings Papers on Economic Activity (Fall). 
Funke, M., M. Schularick, and C. Trebesch. 2016. "Going to Extremes: Politics after Financial Crises, 1870-2014." European Economic Review 88:227-60.

Gallup World Poll. 2016. https://www.gallup.com/analytics/232838/ world-poll.aspx.

Geraats, P. 2009. "Trends in Monetary Policy Transparency.” International Finance 12 (2).

- 2014. "Monetary Policy Transparency." In The Oxford Handbook of Economic and Institutional Transparency, edited by Jens Forssbæck and Lars Oxelheim. Oxford: Oxford University Press.

Global Initiative for Fiscal Transparency (GIFT). 2014. Public Participation and the Budget Cycle: Lessons from Country Examples, Washington, DC.

Government of Sweden. 2011. The Swedish Fiscal Policy Framework. Stockholm.

Guiso, L., P. Sapienza, and L. Zingales. 2006. "Does Culture Affect Economic Outcomes?” Journal of Economic Perspectives 20 (2): 23-48.

Haldane, A. 2017. "A Little More Conversation, A Little Less Action.” Speech at Macroeconomics and Monetary Policy Conference, Federal Reserve Bank of San Francisco, March 31.

Hannoun, H. 2010. “Towards a Global Financial Stability Framework.” Speech at the 45th SEACEN Governors' Conference, Bank for International Settlements, Siem Reap, Cambodia, February 26-27.

Hansen, S., M. McMahon, and M. Tong. 2019. "The Long-Run Information Effect of Central Bank Communication.” Staff Working Paper 777, Bank of England, London.

Hayo, B., and M. Neuenkirch. 2015. "Central Bank Communication in the Financial Crisis: Evidence from a Survey of Financial Market Participants." Journal of International Money and Finance 59:166-81.

Heenan, G., M. Peter, and S. Roger. 2006. "Implementing Inflation Targeting: Institutional Arrangements, Target Design, and Communications.” IMF Working Paper 06/278, International Monetary Fund, Washington, DC.

Helliwell, J. F., H. Huang, S. Grover, and S. Wang. 2014. "Good Governance and National Well-being. What Are the Linkages?" OECD Working Papers on Public Governance 25, Organisation for Economic Co-operation and Development, Paris.

Helliwell, J., and S. Wang. 2010. "Trust and Well-Being.” NBER Working Paper 15911, National Bureau of Economic Research, Cambridge, MA. 
Herradi, M. E. 2017. “The Redistributive Impacts of ECB's Unconventional Monetary Policies: Evidence from Italian Household Surveys."

Iazzolino, G., and N. Stremlau. 2017. "New Media and Governance in Conflict." Third World Quarterly 38 (10): 2242-257.

International Monetary Fund (IMF). 2015. "Evolving Monetary Policy Frameworks in Low-Income and other Developing CountriesBackground Paper-Country Experiences.” IMF Staff Report, Washington, DC.

-.2018a. Fiscal Monitor: Capitalizing on Good Times. Washington, DC, April.

—. 2018b. "Digital Government." In Fiscal Monitor: Capitalizing on Good Times. Washington, DC, April.

. 2019. Joint Responsibility Shared Rewards: The Managing Director's Global Policy Agenda. Washington, DC, April.

Issing, O. 2018 “The Uncertain Future of Central Bank Independence.” In Hawks and Doves: Deeds and Words-Economics and Politics of Monetary Policymaking. VoxEU eBook.

Jain, M., and C. S. Sutherland. 2018. "How Do Central Bank Projections and Forward Guidance Influence Private-Sector Forecasts?” Staff Working paper/Document De Travail du personnel, Bank of Canada, Ottawa.

Kang, Y., A. Koc, X. Luo, A. Muller, J. Pinho, and N. Zagaria. 2013. "Central Bank Communication Policy-A Comparative Study." Columbia University, New York.

Kedan, D., and R. Stuart. 2014. "Central Bank Communications: A Comparative Study." Quarterly Bulletin Articles (April): 89-104.

Kim, J. Y. 2018. Interview on France 24 TV channel, Paris, November 11.

Lagarde, C. 2018. "The Case for the Sustainable Development Goals." The Helen Alexander Lecture, September 17, Washington, DC.

Levin, A. 2014. "The Design and Communication of Systematic Monetary Policy Strategies." Journal of Economic Dynamics and Control 49 (C): 52-69.

Lippmann, W. 1922. Public Opinion. New York: Harcourt Brace.

Lombardi, D., and P. L. Siklos. 2016. "Benchmarking Macroprudential Policies: An Initial Assessment.” Journal of Financial Stability 27:35-49.

Lustenberger, T., and E. Rossi. 2017. "The Social Value of Information: A Test of a Beauty and Non-Beauty Contest." Working Paper, Swiss National Bank, Zurich. 
Mankiw, N. G. 2010. "Questions about Fiscal Policy: Implications from the Financial Crisis of 2008-2009.” Federal Reserve Bank of St. Louis Review 92 (May/June): 177-83.

Marien, S., and M. Hooghe. 2011. "Does Political Trust Matter? An Empirical Investigation into the Relation between Political Trust and Support for Law Compliance." European Journal of Political Research 50 (2): 267-91.

Mbazie, S., and O. M. Ogbulu. 2012. "The Mass Media and the Privatization Campaign: A Survey of the Port Harcourt Public in Nigeria." International Journal of Humanities and Social Science 2 (21): 256-67.

Mishkin, F. 2004. "Can Central Bank Transparency Go Too Far?” In The Future of Inflation Targeting, edited by Christopher Kent and Simon Guttmann. Sydney: Reserve Bank of Australia.

Moessner, R., D.-J. Jansen, and J. de Haan. 2017. "Communication about Future Policy Rates in Theory and Practice: A Survey." Journal of Economic Surveys 31 (3): 678-711.

Nakajima, M. 2015. "The Redistributive Consequences of Monetary Policy." Federal Reserve Bank of Philadelphia Research Department Business Review (Second Quarter).

Norton, A., and D. Elson. 2002. "What's behind the Budget? Politics, Rights, and Accountability in the Budget Process." Overseas Development Institute, Department for International Development, London.

Open Government Partnership. 2017. Trust_The Fight to Win It Back. Washington, DC.

Organisation for Economic Co-operation and Development (OECD). 2001. Citizens as Partners: Information, Consultation and Public Participation in Policy Making. Paris.

- 2009a. Privatization in the 21st Century: Recent Experiences of OECD Countries, Report on Good Practices. Paris.

- 2009b. Policy Responses to the Economic Crisis: Investing in Innovation for Long-Term Growth. Paris.

- 2017. Trust and Public Policy: How Better Governance Can Help Rebuild Public Trust. Paris.

Papademos, L. 2008. "Monetary Policy Communication and Effectiveness." Speech at the Annual Meetings of the Allied Social Science Associations, New Orleans, January 5.

Pescatori, A. 2018. "Central Bank Communication and Monetary Policy Surprises in Chile.” IMF Working Paper 18/156, International Monetary Fund, Washington, DC. 
Pew Research Center. 2015. "Beyond Distrust: How Americans View Their Government.” Washington, DC. www.people-press.org/ 2015/11/23/1-trus t-in-government-1958-2015/.

Phan, T. 2013. "Should Central Banks Publish Interest Rate Forecasts?-A Survey.” MPRA Paper 44676, University Library of Munich, Munich.

Poloz, S. 2016. “The Doug Purvis Memorial Lecture-Monetary/Fiscal Policy Mix and Financial Stability: The Medium Term Is Still the Message." Staff Discussion Paper, Bank of Canada, Ottawa.

Powell, J. H. 2018. "Financial Stability and Central Bank Transparency." Remarks at "350 years of Central Banking: The Past, the Present and the Future," Sveriges Riksbank Anniversary Conference.

Restoy, F. 2018. "Central Banks and Financial Oversight." Speech at the Fundación Ramón Areces, Madrid, June 4.

Roth, F. 2015. "Political Economy of EMU. Rebuilding Systemic Trust in the Euro Area in Times of Crisis." European Commission Discussion Paper 16, Brussels.

Rudebusch, G., and J. Williams. 2008. "Revealing the Secrets of the Temple: The Value of Publishing Central Bank Interest Rate Projections." In Asset Prices and Monetary Policy, 247-89. Cambridge, MA: National Bureau of Economic Research.

Saul, John Ralston. 1997. The Unconscious Civilization, 1995 CBC Massey Lectures, Free Press, New York.

Simon, H. A. 1971. "Designing Organizations for an Information-Rich World." In Computers, Communications, and the Public Interest, edited by M. Greenberger, 37-52. Baltimore: Johns Hopkins Press.

Stankova, O. 2018. "Financial Stability Communications Should Be Strengthened." Central Banking Journal XXVIII (4): 104-09.

Stein, J. 2014. "Challenges for Monetary Policy Communications.” Remarks to the Money Marketeers of New York University, New York, May 6.

Summers, L. H., D. Wessel, and M. Murray. 2018. Rethinking the Fed's 2 Percent Inflation Target. Report from the Hutchins Center on Fiscal and Monetary Policy, Brookings Institution, Washington, DC.

Svensson, L. 2003. "Monetary Policy and Real Stabilization." Working Paper 9486, National Bureau of Economic Research, Cambridge, MA.

—_. 2014. "Forward Guidance." NBER Working Paper 20796, National Bureau of Economic Research, Cambridge, MA.

Swanson, E. 2018. "The Federal Reserve Is Not Very Constrained by the Lower Bound on Nominal Interest Rates.” Brookings Papers on Economic Activity, September 13-14, Brookings Institution, Washington, DC. 
Szyszko, M. 2017. “Central Bank's Inflation Forecast and Expectations. A Comparative Analysis.” Prague Economic Papers 26 (3): 286-99.

Taylor, J. L. 2016. "Independence and the Scope of the Central Bank's Mandate.” Sveriges Riksbank Economic Review 2016 (3).

Tucker, P. 2018. Unelected Power: The Quest for Legitimacy in Central Banking and the Regulatory State. Princeton, NJ: Princeton University Press.

Vagliasindi, M. 2013. Implementing Energy Subsidies Reforms. Evidence from Developing Countries. Washington, DC: World Bank.

Vayid, I. 2013. "Central Bank Communications before, during and after the Crisis: From Open-Market Operations to Open-Mouth Policy." Working Paper 2013-41, Bank of Canada, Ottava.

Weidman, J. 2018. "Central Bank Communications as an Instrument of Monetary Policy." Lecture at the Centre for European Economic Research, Mannheim, May 2.

Wilkins, C. A. 2017. “Toward the 2021 Inflation-Target Renewal.” Closing Remarks of the Workshop on Monetary Policy Framework Issues. Ottawa, Ontario, September 14.

_. 2018a. "Choosing the Best Monetary Policy Framework for Canada." Remarks at McGill University Max Bell School of Public Policy, Montréal, November 20.

_. 2018b. "Financial Stability: Taking Care of Unfinished Business." Speech at Rotman School of Management conference "Are We Ready for the Next Financial Crisis?” Toronto, March 22.

Williams, J. C. 2015. "Monetary Policy and the Independence Dilemma." Presentation at Chapman University, Orange, California, May 1.

Woodford, M. 2001. "Monetary Policy in the Information Economy." Proceedings of the Economic Policy Symposium of the Federal Reserve Bank of Kansas City Symposium, Jackson Hole.

- 2005. "Central Bank Communication and Policy Effectiveness." Proceedings of the Economic Policy Symposium of the Federal Reserve Bank of Kansas City Symposium, Jackson Hole, 399-474.

_ 2008. "Forward Guidance for Monetary Policy: Is It Still Possible?" VoxEU article, January 17. https://voxeu.org/article/forward-guidance -monetary-policy-it-still-possible.

Yellen, J. 2012. "Revolution and Evolution in Central Bank Communications." Remarks at Haas School of Business, University of California, November 13. 